\title{
The Dasanech of the Lowermost Omo Basin: From Adaptation to Development Debacle
}

\begin{abstract}
The decline of Dasanech pastoral economy in recent decades, due to increasing marginalization by powerful external political and economic forces, has forced the majority of Dasanech to move to areas along the Omo River and its active delta or around the northeastern shores of Kenya's Lake Turkana. Radical reduction of river flow volume, lake retreat and elimination of the river's annual flood brought about by the Gibe III dam, together with dam enabled irrigation agricultural enterprises, would destroy the key components of Dasanech livelihood. Most flood recession agriculture would be eliminated, along with 'last resort' livestock grazing lands, forest resources and fish reproductive habitats in the lowermost Omo and Lake Turkana northern shoreline. Even if the highly unlikely and in any case inadequate artificial flood program promised by the Ethiopian government were implemented, Dasanech survival systems would have already been decimated. The looming crisis of region-wide hunger and mortality is intensified by the Ethiopian government's eviction and expropriation of thousands of Dasanech villagers for large-scale irrigated commercial agriculture. Political repression and a culture of fear prevail. As the crisis unfolds, Dasanech communities, faced with vanishing means of survival, would inevitably contribute to rapid escalation of cross-border, interethnic armed conflict.
\end{abstract}

\section{Dasanech Pastoral Decline: Roots and Responses}

$>$ Throughout the first half of the twentieth century, the Dasanech pastoralists sustained a system of wide-ranging movements throughout the region's dryland plains, as did other indigenous groups in the transboundary region. These movements ranged across different types of habitats (Carr 1977; Bassi 2011), facilitating diversified food production and complex patterns of risk minimization, as described in Chap. 4.

By the second half of the century, the combination of direct territorial restriction by the Kenyan and Ethiopian governments, conflict with other disenfranchised pastoral groups in the region and other pressures effectively confined the Dasanech to the plains west of the Omo River and east of the Kibish River for many years. The Dasanech were forced to relinquish most of these areas:

- The upland plains of the Ilemi Triangle - formerly, a 'buffer zone' created by agreement between the Ethiopian monarchy and the Kenyan colonial administration. 
- Grasslands in the Kenya/Ethiopia border area to the northwest of Lake Turkana and southeast of the Ilemi Triangleespecially critical during drought periods. ${ }^{1}$

- Woodlands and grasslands along the Kibish River, Koras Mountain and much of the pasture lands between Koras Mountain and the Omo River (Fig. 1.3)—lands previously shared with the Nyangatom but increasingly fought over as resource degradation and loss of land access have taken hold in the region.

- Semi-arid plains and relatively wetter foothills east of the lowermost Omo River, due to hostilities with the Hamar group to the east (Fig. 1.3).

These territorial restrictions caused severe overcrowding of Dasanech livestock, with a loss of access to critical resources during prolonged drought and other stress periods. Centuries old risk minimization and recovery strategies of the Dasanech were no longer effective. With no relief available to them, the Dasanech were subjected to continued deterioration of their lands, and the herds of individual pastoral families plummeted.

While Dasanech pastoralism persisted in the second half of the twentieth century (Fig. 7.1), their livelihood was severely threatened to the point where major adjustments were necessary for their survival.

$>$ Widespread ecological degradation was evident throughout much of their remaining territory by the late 1960s and early 1970s. Instead of the uniquely complex, mosaic-like complex of habitats and vegetation, vast areas became susceptible to invader species of plants - a process that has continued to the present. This writer studied the structure and floristics of 'natural' versus disturbed grassland communities in major plains habitats, including including relict sandy beach ridges, black cracking (margallitic) clay basins and ancient floodplains adjacent to the Omo River (Carr 1977). There are some common features of ecological deterioration in these different communities:

- Sharp reduction of total vegetation cover with the creation of significant bare areas.

- Invasion and spread by numerous 'disturbance indicator' plant species-mostly unpalatable species.

- Increasing erosion (both water and wind driven) with the loss of topsoil. Much of this degradation is irreversible in practical terms, particularly once sheet erosion and certain species invasion occur (most recently, Acacia nubica, A. horrida and Prosopis juliflora - the last of these, an introduced species, has spread throughout the region). Vast areas are now with negligible plant cover and susceptible to intensive wind and water erosion.

This writer (Carr 1977) described 'phases' of this deterioration for much of the lowermost Omo basin based on construction of ecological (vegetation and soil) transects along a gradient of grazing pressure in the above geomorphic units (Figs. 7.2 and 7.3). ${ }^{2}$

Most Dasanech pastoral lands are now so severely degraded that their recovery potential is in serious question, even under the best of circumstances.

$>$ Dasanech elders uniformly describe the degradation of their grasslands as the most important change in their survival efforts, at least until the recent aggressive policies by the GOE along the Omo River. The statement of one Dasanech elder on the west bank, recorded in 2011, is illustrative of the narratives throughout Dasanech lands.

When I was a young man, our land was big. Now we don't live in those lands, as the governments have taken them from us, and now they let others into our lands. Once we had the lands of good grass, but now we have no grass except for short times when the rains come, and even then the grass goes away quickly. Before, there were so many wild animals roaming the land: topi, oryx, wildebeest, lion, cheetah, foxes and many more. Now most of them are gone. Have they gone north? Or west? They have been chased away by the loss of grass that is killing our cattle too, and killed by poachers and by those who have gotten many guns from the war.

\footnotetext{
${ }^{1}$ The British administrator from Kenya (Mr. Whitehouse) who played a key role in the decision to remove the Dasanech (termed the "Marille" by the Kenyan government) from this region described to this writer that no account was taken of the Dasanech population or neighbors' survival needs in boundary determination.

${ }^{2}$ Grassland and other vegetation types west of the Omo River are determined by a combination of factors including ancient sediment depositional patterns (for example, alluvial and fluvial — with soils ranging from silty clay relict floodplains through margallitic, or black cracking soils to sandy beach ridges) and land use pressures.
} 

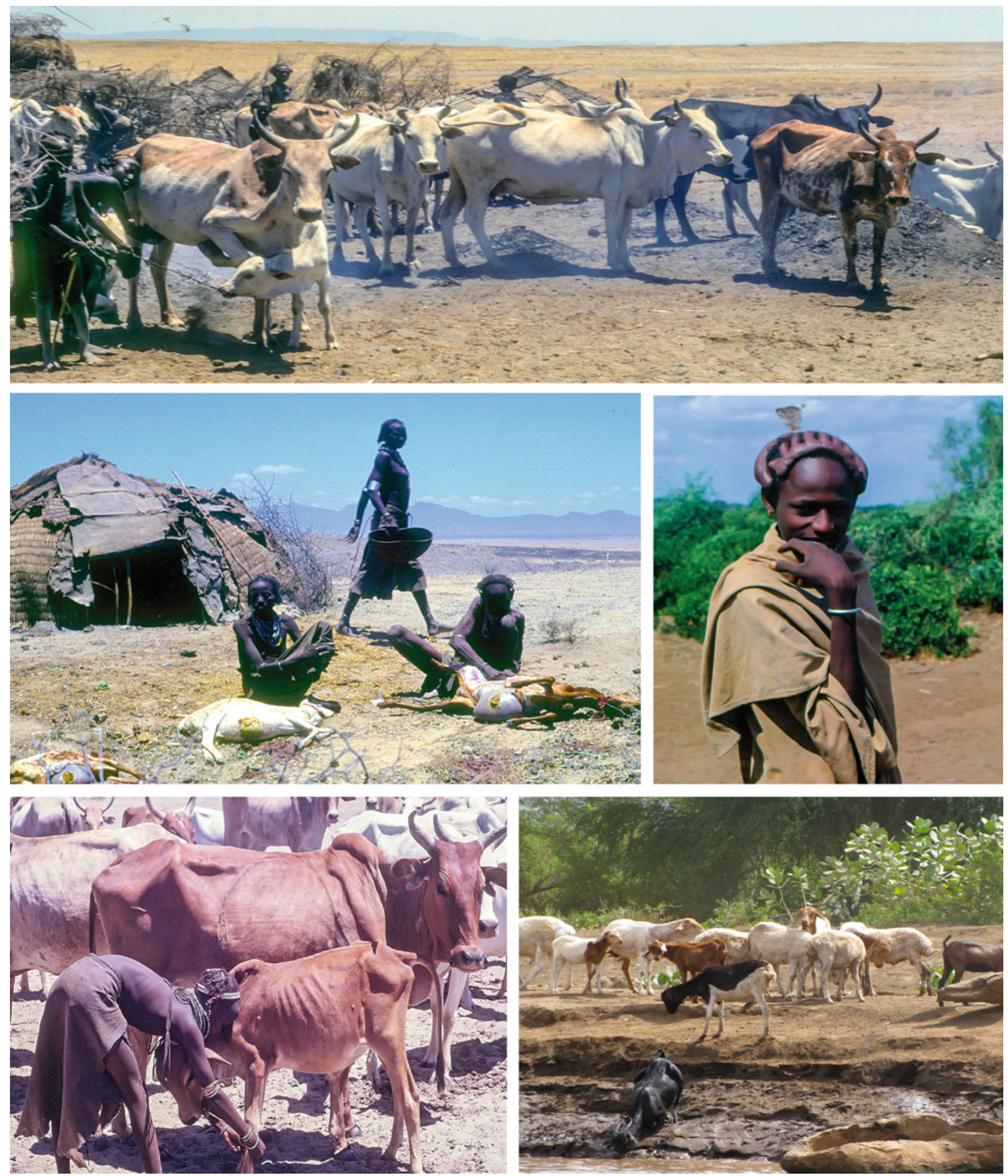

Fig. 7.1 Dasanech herders and livestock. Top Cattle at pastoral village in highly overgrazed area. Center left Women slaughtering goats in pastoral village. Center right Young male herder at stock camp. Bottom left Mid-day milking. Bottom right small stock watering at Omo River 


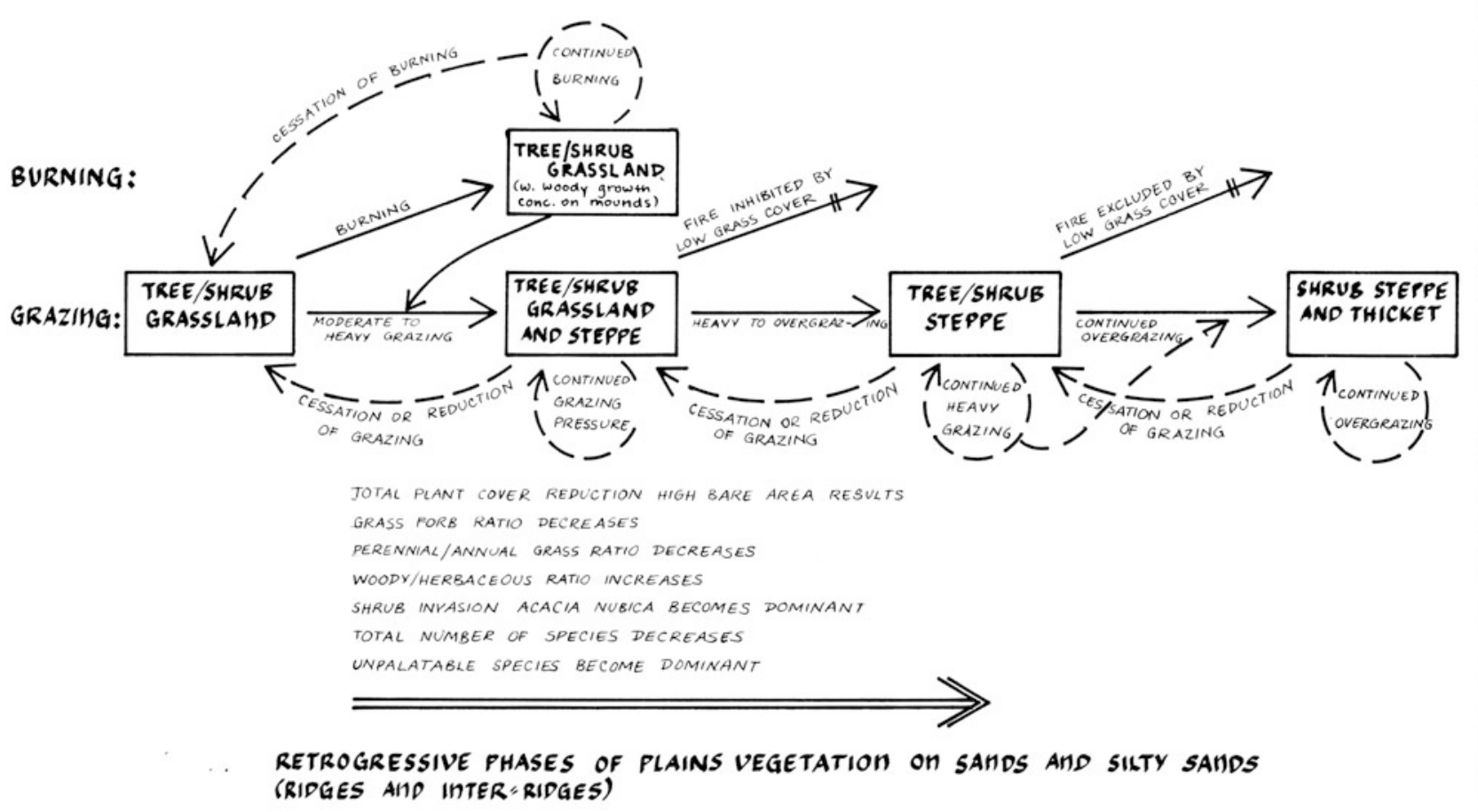

Fig. 7.2 Pasture deterioration phases in upland plains. Dominant and comparable soil type in Dasanech region of the lower Omo basin (sandy-silt soils on relict beach/interridge areas)

Pastoral Dasanech households (Fig. 7.4) attempted to recover from unprecedented resource losses by any means possible. Among other adjustments, they altered their seasonal herding patterns, lessened the mobility of villages-relying instead on highly mobile stock camps, utilized all types of social cooperation and exchange relationships, and engaged in raiding of neighboring groups deemed hostile at the time. This writer studied these complex patterns during the 1970s, with herd sizes, seasonal movements and production activities recorded for six different village areas, indicated in Fig. 7.5 (Carr 1977).

The differentiation of Dasanech social segments is reflected in the 'nodes' of pastoral settlement: for example, the Rendelli segment is distinguishable from Inkabela and Oro segments. These patterns were identified by this writer (Carr 1977) and are summarized in Fig. 7.5. At the time, most Dasanech were pastoralists residing in the upland plains - taking their livestock to the Omo River primarily during the dry seasons and especially during prolonged drought periods. Those Dasanech households engaged in flood recession agriculture along the Omo River went there primarily during periods of intensive farming labor, although some Dasanech were well-established there in semi-permanent villages. A significant proportion of villages along the river were of the Eleli segment of the Dasanech, for example. Some of the poorest Dasanech had already begun fishing in the lowermost delta and along Lake Turkana's northern shoreline in the delta.

A series of prolonged drought periods in the region during the 1970s and 1980s, accompanied by increased livestock raiding between the Dasanech, and their neighbors - especially the Turkana and Nyangatom, greatly worsened Dasanech coping efforts. Herd numbers plummeted for the vast majority of households. Kenyan officers administrating the Ilemi Triangle began permitting Turkana pastoralists back into Ilemi lands by the 1980s, so even the longstanding 'illegal' but persistent use of the Ilemi by the Dasanech became sporadic, at best. This situation continues to the present day. 

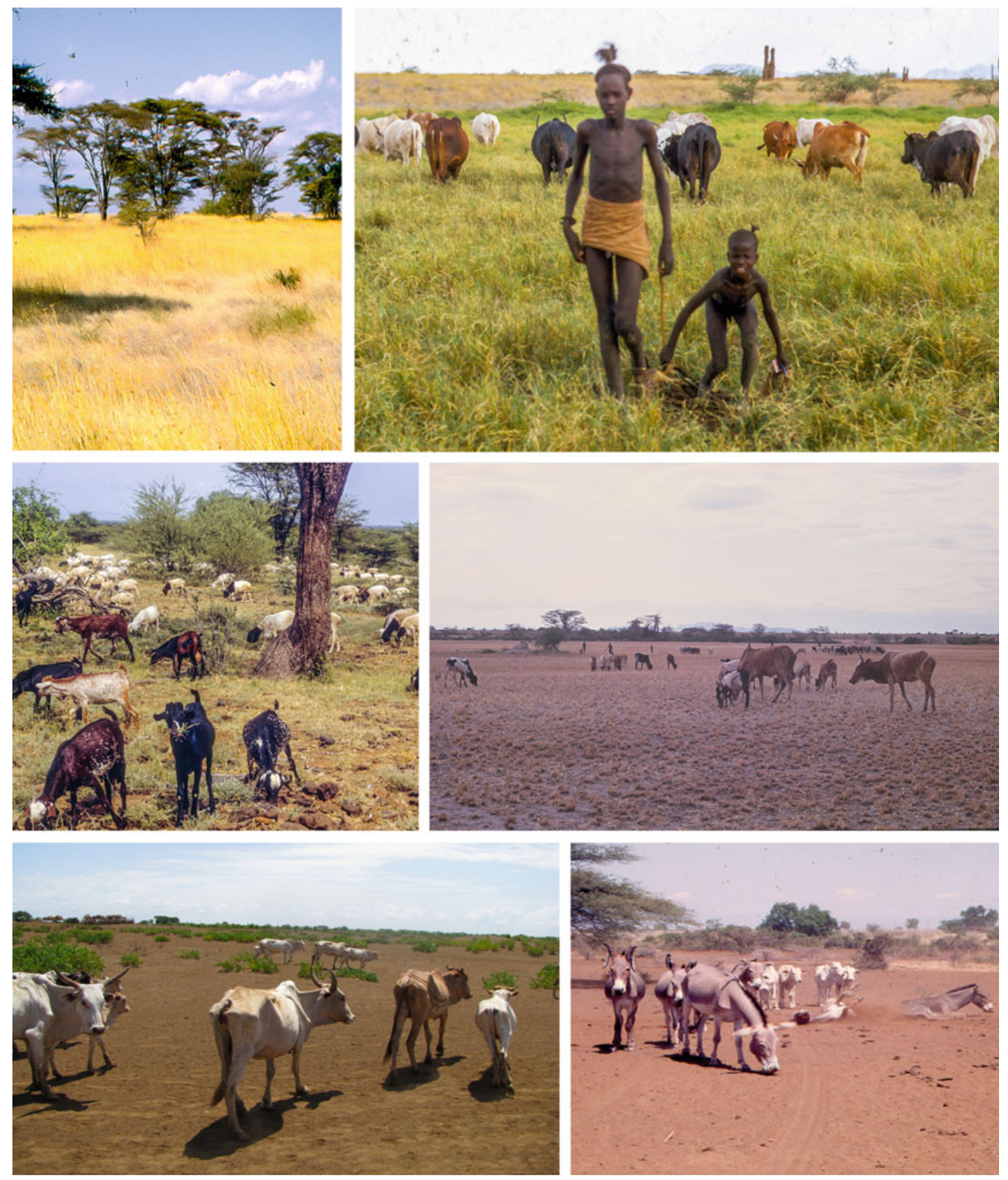

Fig. 7.3 Phases of ecological decline in lower Omo basin pastoral lands. Top left Ilemi Triangle 'healthy' grassland-well-drained silty/sand relict beach ridge. Top right young herders with cattle in seasonally inundated cracking clay grassland basin within the Ilemi Triangle with relict beach ridge behind. Center photos two intermediate overgrazed conditions in silty/sand soils with discontinuous cover and plant 'invader' species. Bottom photos Severely overgrazed conditions; left - unpalatable vegetation (e.g., Cadaba rotundifolia, Euphorbia nubica) severely malnourished cattle

The urgency for additional grazing lands for Dasanech livestock in these three different environments emerged from a combination of factors, including:

- Worsening environmental degradation of the dryland plains, due to overgrazing, with increased livestock mortality and herd losses.

- Increasing hostilities with neighboring groups, particularly the Turkana and Nyangatom.

- Continued exclusion from the Ilemi Triangle (and contiguous lands dominated by the Turkana). 

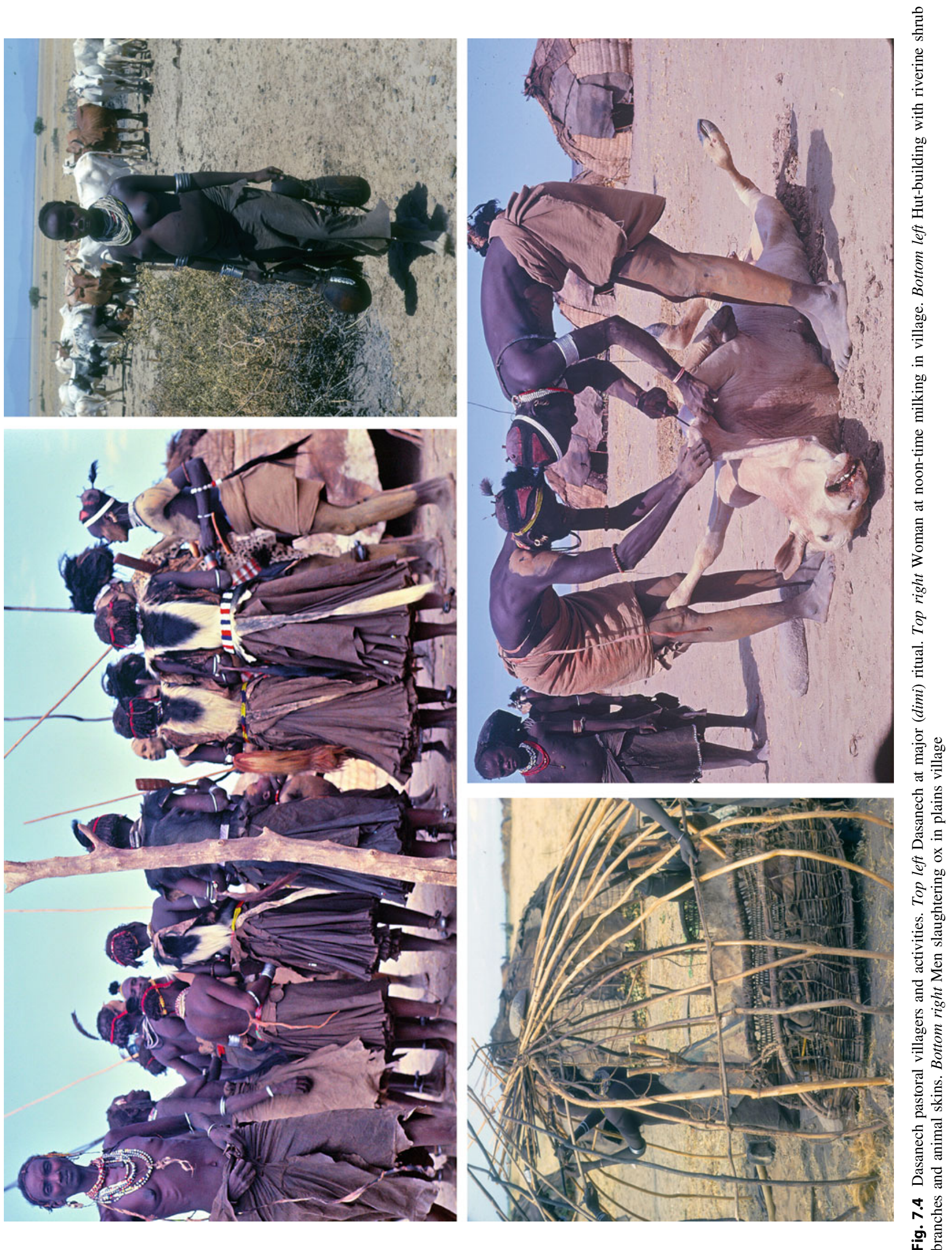

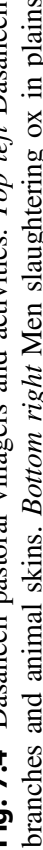




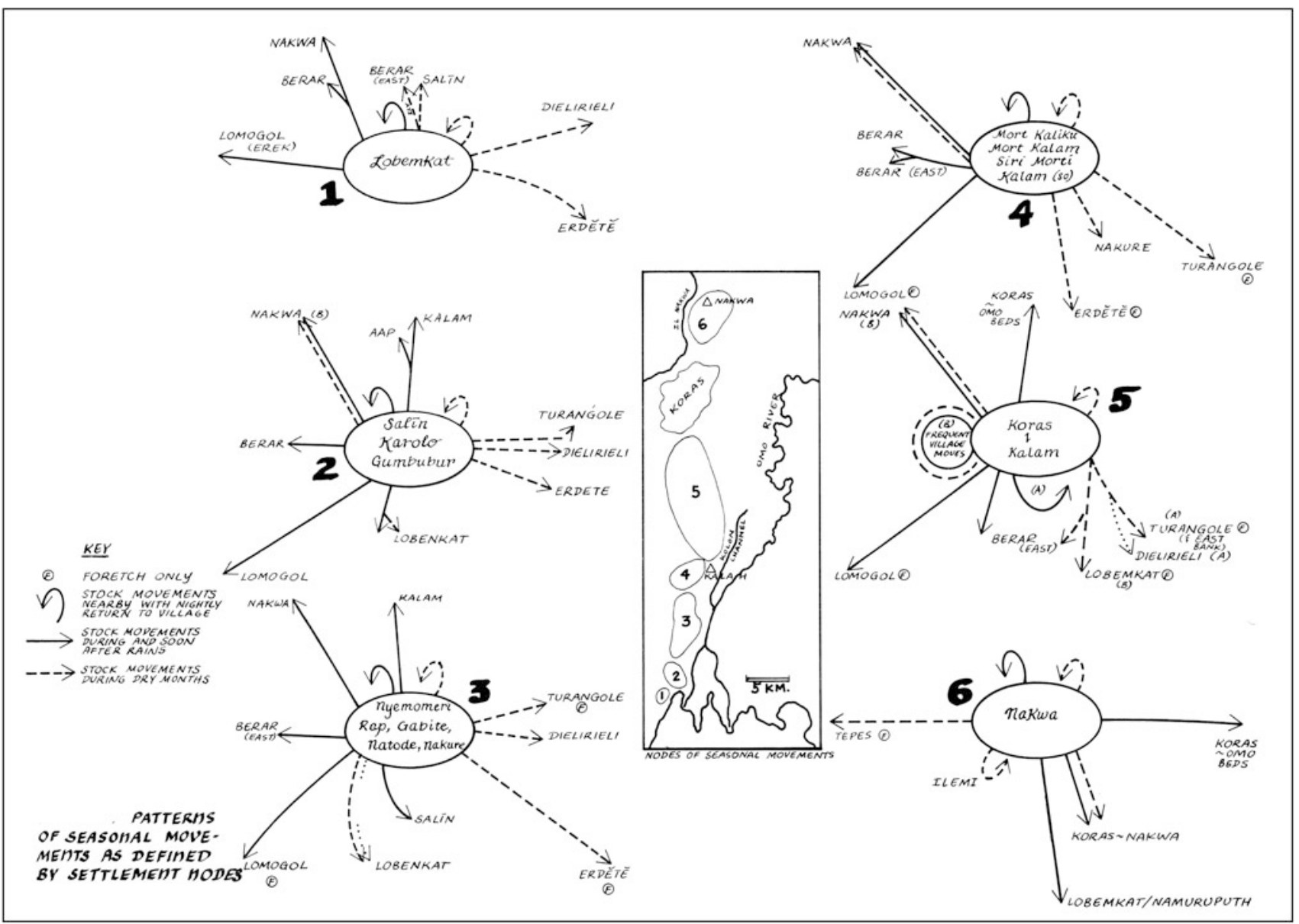

Fig. 7.5 Seasonal movement patterns of six Dasanech settlement areas west of the Omo River. Source Carr (1977)

Conflicts between Dasanech and Nyangatom communities intensified, as both groups competed for water and grazing at the seasonally flowing Kibish River, where they have long done extensive well digging in the dry months, in lands around Koras Mt. and eastward to the Omo River (Fig. 1.1). They also competed for settlement, wild food gathering and hunting locales along the Omo River. Similar conflict relations existed with the northern Turkana—primarily over access to the Ilemi region and the grasslands of the Ethiopia-Kenya border region northwest of Lake Turkana. Venturing into these lands for the Dasanech was at great risk - both because of possible Turkana and Nyangatom attack and because of seizure of their livestock and sometimes shootings by Kenyan police.

\section{Adapting from Upland Pastoral Life to Diversified Economy at the River}

Faced with rapidly diminishing herds and environmental degradation throughout their pasturelands, by the early 1980s, Dasanech pastoralists had no choice but to rely on the Omo riverine zone and lake environments, both for last resort grazing and economic diversification to recession agriculture. The only real options for them were locales (i) within the delta, which was actively expanding (see Chap. 1), (ii) along the river upstream from the delta to the southern extent of the Nyangatom - initially, along the west bank (due to the danger of attack from the Hamar to the east), and (iii) around the northeastern shoreline of Lake Turkana to Ileret, Kenya — and southward along the lake (Fig. 1.3). At first, most Dasanech settlements in these area were seasonal, but over time many of them remained throughout the year.

The overall migration pattern is shown in Fig. 7.6. Some Dasanech pastoralists remained highly mobile, even with greatly diminished herds. The more mobile pastoral households continued sending stock camps to the eastern Ilemi Triangle from 


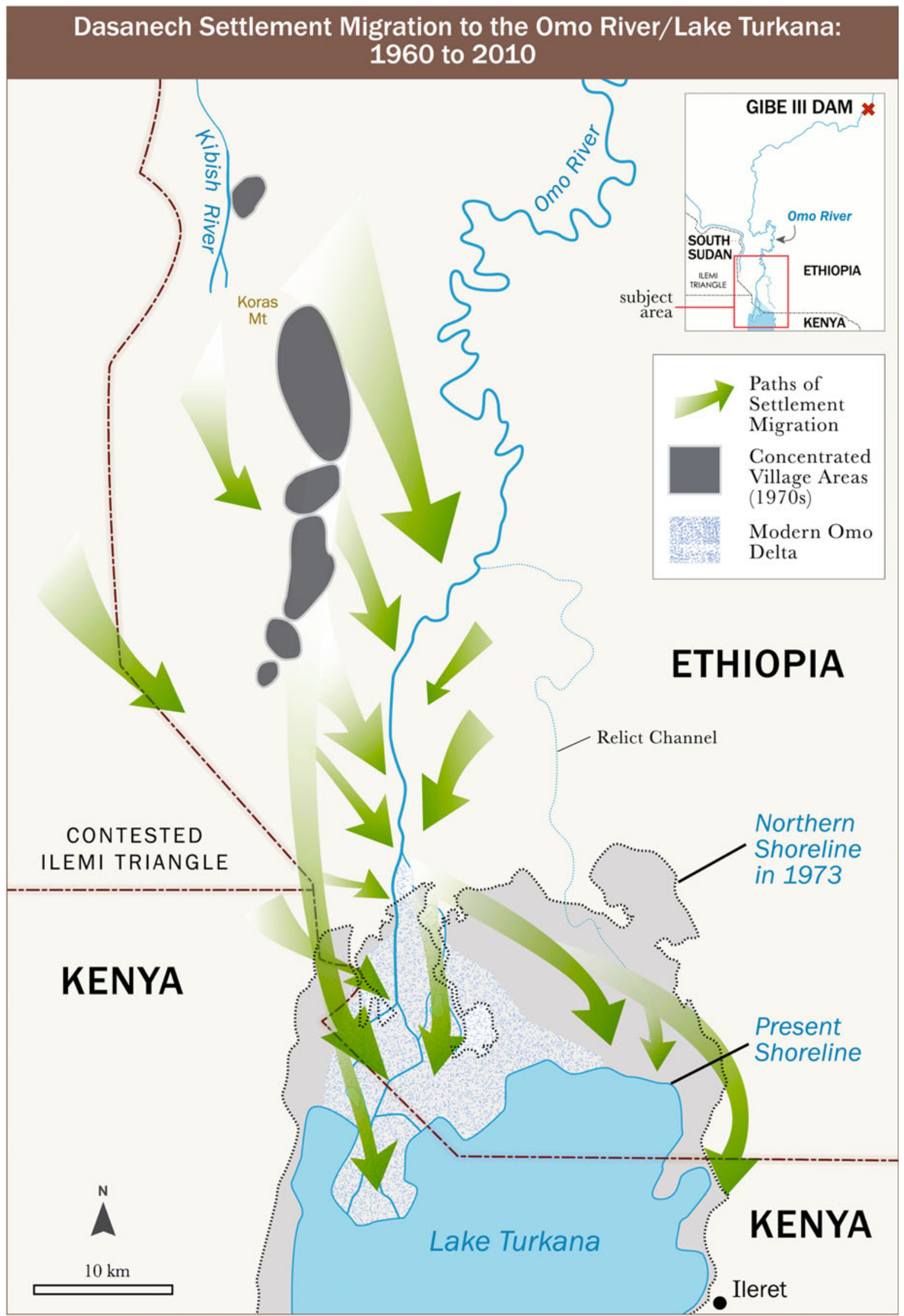

Fig. 7.6 Dasanech settlement migration from upland plains to Omo riverine zone: 1960-2011 
which they were officially excluded, as well as around Koras Mountain and the Kenyan-Ethiopian border areas-including the coveted grazing lands of Meyen and Labur. (Their use of the Ilemi lands, however, was with strong risk of having their livestock seized by police and herding in the border lands and around Koras Mountain carried equal danger of attack by the Turkana and Nyangatom (a reciprocal threat that remains and intensifies in times of stress).

In spite of these efforts to access their traditional lands, Dasanech pastoralists continued to suffer major cattle and small stock losses. They became increasingly dependent on the Omo River zone for both water and pasturage. Even pastoral villages remaining several kilometers away from the Omo River had at least some family members engaged in food production in the riverine zone-primarily flood recession agriculture and fishing.

Several new possibilities for Dasanech livelihood activities emerged during the 1980s, even though these have been wholly insufficient to compensate for their massive economic decline.

- The Omo delta began a period of expansion southward, with its terminus extending well into Kenya's Lake Turkana (Fig. 1.2). This new delta area has amounted to more than $500 \mathrm{~km}^{2}$ for possible new settlement as well as livestock grazing, flood recession agriculture and fishing.

- Local Kenyan officials began permitting the Dasanech to return to the arid lands around the northeastern shoreline of Lake Turkana where the group had once resided. Large numbers of Dasanech, particularly from one cultural segment, responded to this opportunity. In fact, many of them continued southward from Ileret to their fluctuating border with the Gabbra (Fig. 1.3). Relations between the Dasanech and Gabbra are generally hostile although they were once largely peaceful, with resource sharing in many locales. Hostilities have intensified as available pasturage has disappeared.

Settlement shifts by most Dasanech from their degraded upland plains to the Omo River and Lake Turkana environments directly reflects the failing economic conditions for the group as a whole. ${ }^{3}$ Many Dasanech who settled west of the Omo began moving back to the riverine zone on the east bank of the Omo River-lands where they had resided decades earlier. The danger of attack by the Hamar to the east effectively confined their villages and herds close the river.

A variety of village and household livelihood patterns have emerged, but with overall economic decline and shift in food production activities (Fig. 7.7). Despite the Dasanech's long-term cultural dislike of fishing, an increasing number of the poorest households have had no choice but to begin fishing in the channels of the lowermost Omo River or the northernmost waters of Lake Turkana. The number of fishing households has increased substantially since the 1980s, for several reasons. first, the plains environment and livestock herds have continued to deteriorate; second, the traditional lands of the Ilemi were no longer available; and third, the Ethiopian government has evicted thousands of villagers from their riverine landsforcing most of them into the already crowded Omo delta where planting land is scarce. A wide variety of subsidiary but essential livelihood activities are carried out in both riverine and upland areas (Fig. 7.8).

$>$ Tens of thousands of Dasanech now reside in three major areas along the lowermost Omo River-the west bank, the east bank and the active delta region. There are no reliable demographic data for these Dasanech, despite the obvious importance of such information for a detailed assessment of the human impacts that would be caused by the Gibe III dam. SONT researchers identified major Dasanech village areas that are variously seasonal or of year-round duration. Village areas recorded and the large zone of GOE expropriation of villagers from their settlements and riverside lands are indicated in Fig. 7.9.

GOE population estimates vary from 40,000 to more than 200,000 . The Ethiopian government's census results were clearly projections rather than actual village based counts-projections likely generated in towns well removed from Dasanech settlements. Villagers throughout the region emphatically state that neither government nor other individuals have

\footnotetext{
${ }^{3}$ Although strong differences in wealth have long existed, the resulting precipitous herd decline affected the Dasanech as a whole, since those stock owners fortunate enough to retain larger herds were obliged to distribute at least some of their wealth to varying combinations of clan, age-set and affine (in-law) relations. These social structural relations are best described by Almagor (1978).
} 
Primary Livelihood Shifts: 1970 - 2010

$\underline{\text { Principal Resource Area }}$

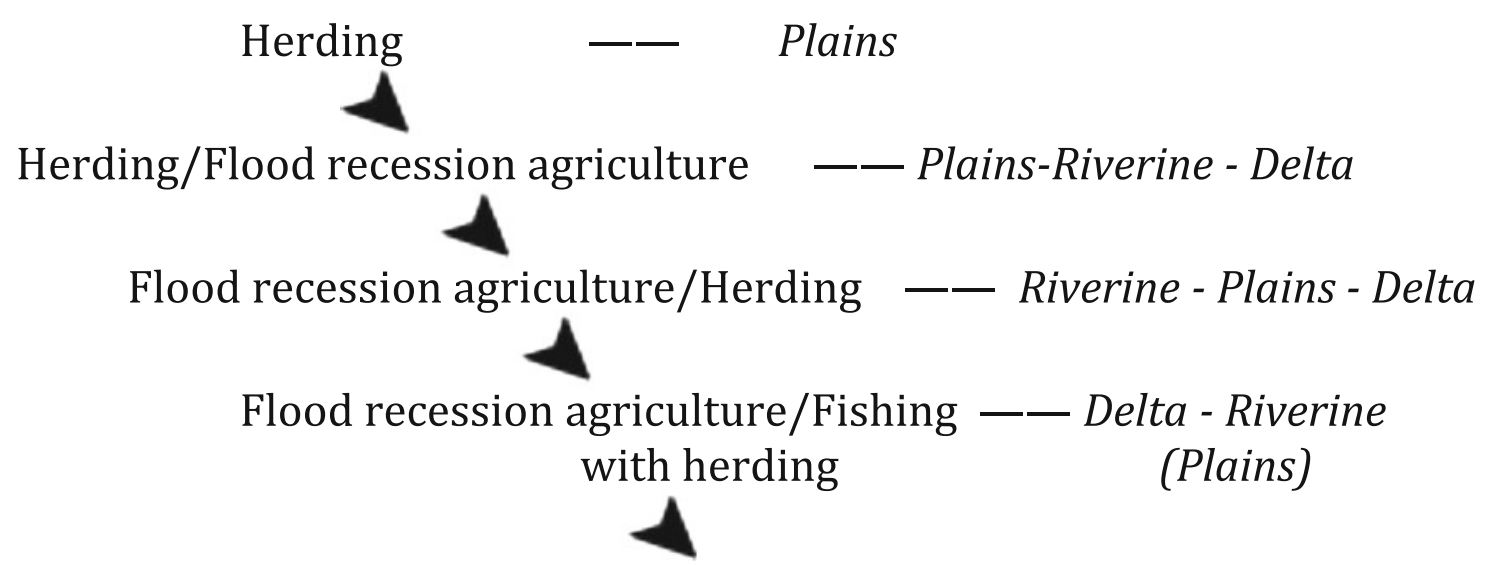

Fishing / Flood recession agriculture - Delta - Riverine

Fig. 7.7 Major Dasanech livelihood decline from upland pastoral economy (west side of the Omo River)

visited to record census information. ${ }^{4}$ Staff members of non-governmental organizations engaged in periodic relief operations amongst the Dasanech expressed their frustration at having to rely on official government estimates.

Any figure between these extremes points to the major numbers of Dasanech whose lives are threatened by the Gibe III dam and dam enabled irrigated agricultural development.

It is likely that the European Investment Bank's impact report (EIB 2010) relied on GOE population figures, given the EIB consultant's statement that the duration of its field investigation of the entire area from the Gibe III dam to Lake Turkana was only ten days. Such a period is wholly inadequate for even a minimally acceptable population sampling among the Dasanech. Estimates based on satellite imagery without extensive ground-based investigation would be entirely inaccurate, since Dasanech village complexes fluctuate in location — sometimes extremely rapidly —in response to shifts in pasturage, water, disease, immediate security and other conditions. Moreover, villages visible in satellite images are often abandoned ones, or reoccupied by another ethnic group - especially common in contested areas. There are also major Dasanech settlement shifts between Kenya and Ethiopia, reflecting rapidly changing environmental and socioeconomic conditions.

SONT researchers could not conduct systematic population counts, due to GOE restrictions and widespread fear of government reprisals by villagers. Dasanech village areas were therefore identified only through ground reconnaissance, and primarily during the dry season (Table 7.1). Small scattered villages were not recorded.

The combination of information from all reliable sources, including SONT's own field-based investigation in selected village areas and several non-governmental officials interviewed, suggests a minimum Dasanech population of 60,000 to 70,000 - an approximate figure, at best. Whatever the accurate figure for the Dasanech population, it is clear that there are tens of thousands of them residing along and nearby the Omo River with their livelihood dependent on sustainment of and access to the Omo River.

\footnotetext{
${ }^{4}$ These villager statements were corroborated by a senior government officer in Omorate (see Fig. 1.3 and maps below), who affirmed to this writer that no ground census had been carried out.
} 


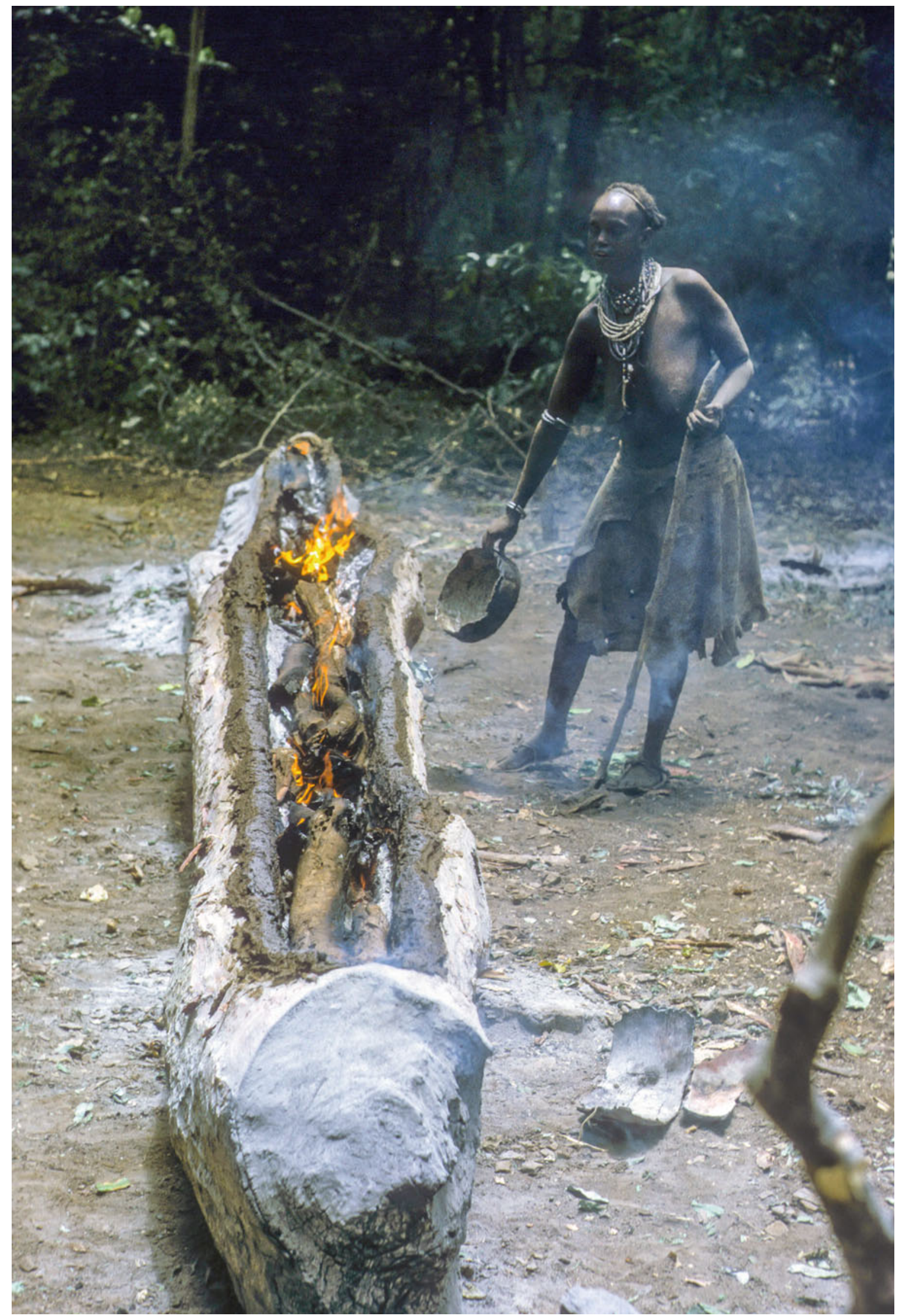

Fig. 7.8 Dasanech woman making dugout canoe from a tree trunk in a small clearing in the Omo riverine forest 


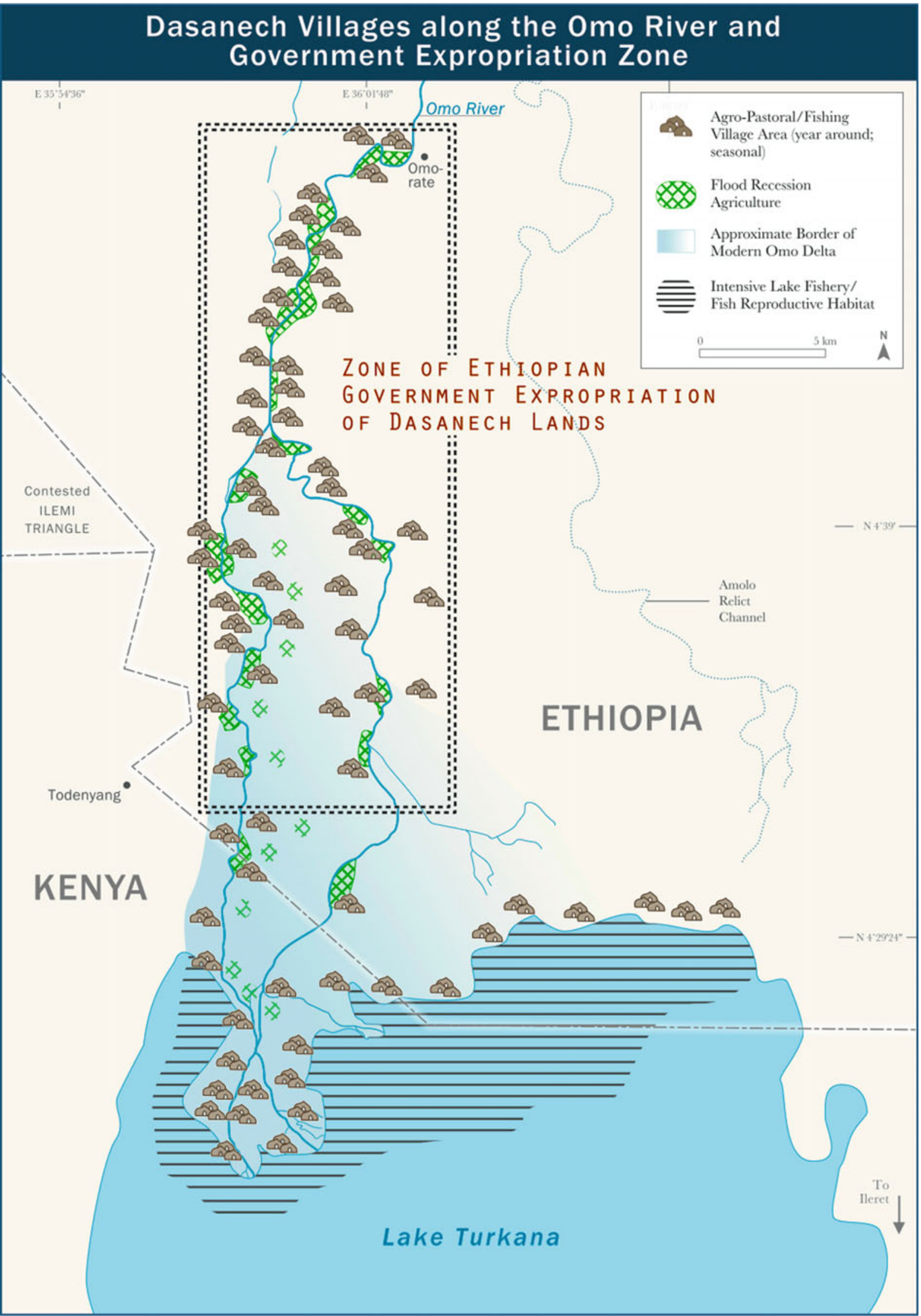

Fig. 7.9 Zone of Ethiopian Government Expropriation of Dasanech villages and livelihood areas 
Table 7.1 Dasanech village complexes along the Omo River: 2009-2010

\begin{tabular}{l|l|l}
\hline West bank & East bank & Modern delta \\
\hline Goto & Afuor & Lomosia \\
Damish & Kapuse & Ngymoru_Lulung \\
Akudingole & Tieli rieli & Ediporo \\
Nyemomeri & Lobele & Kipur-cheria \\
Atalago & Edete & Andora/Ililokelete \\
Salany (Salin) & Lobaoi & Bokom (both banks of channel) \\
Lochuch & Apaluka_(largely fishing) & Lonyangereng \\
Koro & Derish & Nakabila \\
Bokom & Aluuli & Chongochongo \\
Olmin & Loyere, Nyikiki_east of Omo River zone) & Aachuun \\
Gabite & & Jiete-Konya \\
Toltale & & Budori \\
Malsipi & & Nakoida \\
Terishichess & & Araloput \\
Tuushe & & Lokielinya \\
Turite & & Kaakulu \\
Lopelebin & & Koranyilutu (Koro Nyingabite) Naichari \\
Naakale & & \\
\hline
\end{tabular}

Three areas of villages were identified: west bank, east bank and active (modern) delta

While these villages (many of which are included in the map of Fig. 7.9) were recorded during the dry season and some of them are seasonally mobile or have shifted altogether, their presence during all or part of the year indicates the extreme dependency of the Dasanech on riverine resources.

- The economic decline of the Dasanech, the dominant sequence of which is summarized Fig. 7.7, is evident from household data collected by this writer, in 1970/1972 and 2009/2010. Of 75 households surveyed in the 1970s, information was updated for 35 of them in the latter period (Table 7.2). Households from the original survey were randomly selected from four of the six major pastoral settlement areas indicated in Fig. 7.5.

A number of patterns are evident from these household timeline data:

- All of the 35 households recorded had relocated - mostly to the riverine/delta zone - due to major changes in their key production activities. ${ }^{5}$ Most had diversified their production from herding to include flood recession agriculture or fishing, or both. Nearly all households moved part or all of their members to the riverine/delta region, seasonally or year round. Significant shifts in authority and other social relations have accompanied these changes (Fig. 7.10).

- Precipitous herd decline has overwhelmingly driven this economic transformation (with minor exception). Some households lost all livestock; most lost a quarter to two-thirds of their cattle, while small stock losses varied considerably.

- As cattle herds have declined, Dasanech herders have relied more on small stock since they are far more adapted to degraded pastures and to days without watering. Dasanech long-term cultural preference for cattle over small stock has been dominated by this necessary shift.

Dasanech herd owners on the west bank and in the delta were interviewed concerning their loss of livestock to disease. A typical response was:

Only a few people near Omorate got help for livestock diseases. Those living in the delta and the whole west bank received no help from the government.

- Some herd owners diversified their economic production and managed to partially rebuild small stock herds though barter or sale of grain or fish.

\footnotetext{
${ }^{5}$ The relative similarity or difference between the specific household in question and neighboring ones from the original sample was also recorded. Names of household heads are excluded for the protection of individuals.
} 
Table 7.2 Dasanech household wealth status and livelihood change. Households from west bank of the Omo River: 1972 versus 2009

\begin{tabular}{|c|c|c|c|c|c|c|c|c|c|c|}
\hline \multirow[b]{2}{*}{$\begin{array}{l}\text { Household } \\
\text { Number }\end{array}$} & \multicolumn{5}{|c|}{1972} & \multicolumn{5}{|c|}{2009} \\
\hline & $\begin{array}{l}\text { Village } \\
\text { Location } \\
\text { P-Plains } \\
\text { R-River } \\
\text { D-Delta }\end{array}$ & $\begin{array}{l}\# \\
\text { Cattle }\end{array}$ & $\begin{array}{l}\# \\
\text { Goats } \\
\text { Sheep }\end{array}$ & Farm & Fish & $\begin{array}{l}\text { Village } \\
\text { Location }\end{array}$ & $\begin{array}{l}\# \\
\text { Cattle }\end{array}$ & $\begin{array}{l}\# \\
\text { Goats } \\
\text { Sheep }\end{array}$ & Farm & Fish \\
\hline 1 & $\mathbf{P}$ & 140 & 180 & No & No & $\mathbf{P}$ & 38 & 30 & Yes & No \\
\hline 2 & $\mathbf{P}$ & 150 & 45 & No & No & P/R & 40 & 48 & Yes & No \\
\hline 3 & $\mathbf{P}$ & 60 & 0* & No & No & $\mathbf{R} / \mathbf{D}$ & 18 & 30 & Some & Some \\
\hline 4 & $\mathbf{P}$ & 28 & 65 & No & NO & $R / D$ & 5 & 22 & Yes & No \\
\hline 5 & $\mathbf{P}$ & 47 & $5^{*}$ & No & No & D & 0 & 0 & No & Yes \\
\hline 6 & $\mathbf{P}$ & 280 & 350 & No & No & R/D & 15 & 0* & Yes & Yes \\
\hline 7 & $\mathbf{P}$ & 44 & 60 & Yes & No & $\mathbf{R} / \mathbf{D}$ & 18 & 24 & Yes & No \\
\hline 8 & $\mathbf{P}$ & 120 & 210 & No & No & $\mathbf{R}$ & 35 & 68 & Yes & No \\
\hline 9 & $\mathbf{P} / \mathbf{R}$ & 32 & 44 & Yes & No & D & 0 & 5 & Some & Yes \\
\hline 10 & $\mathbf{P} / \mathbf{R}$ & 30 & 12 & Yes & No & D & 2 & 0 & No & Yes \\
\hline 11 & $\mathbf{P}$ & 310 & 155 & No & No & $\mathbf{R}$ & 34 & 50 & No & No \\
\hline 12 & $\mathbf{P}$ & 41 & 15 & No & No & $\mathbf{R} / \mathbf{D}$ & 15 & 33 & Yes & Some \\
\hline 13 & $\mathbf{P}$ & 58 & 40 & Some & No & $\mathbf{P} / \mathbf{R}$ & 22 & $6^{*}$ & Yes & No \\
\hline 14 & $\mathbf{P}$ & 155 & 85 & No & No & $\mathbf{P} / \mathbf{R}$ & 10 & 34 & Yes & No \\
\hline 15 & $\mathbf{P}$ & $\mathbf{5 5 0}$ & 200 & No & No & $\mathbf{P} / \mathbf{R}$ & 18 & 400 & No & No \\
\hline 16 & $\mathbf{P} / \mathbf{R}$ & 50 & 30 & Yes & No & D/R & 12 & 22 & Yes & (Yes) \\
\hline 17 & $\mathbf{P}$ & 210 & 60 & Yes & No & $\mathbf{R}$ & 32 & 85 & Yes & No \\
\hline 18 & $\mathbf{P}$ & 800 & 110 & No & No & $\mathbf{R}$ & 160 & 60 & No & No \\
\hline 19 & $\mathbf{P}$ & 540 & 85 & No & No & $\mathbf{P}$ & 105 & 73 & (Yes) & No \\
\hline 20 & $\mathbf{P}$ & 65 & 38 & Yes & No & $R / D$ & 40 & 55 & Yes & (Yes) \\
\hline 21 & $\mathbf{P}$ & 75 & 22 & No & No & $R / D$ & 14 & 5 & Yes & No \\
\hline 22 & $\mathbf{P}$ & 0 & 8 & Yes & No & D & 0 & 0 & No & Yes \\
\hline 23 & $\mathbf{P}$ & 80 & 130 & (Yes) & No & $\mathbf{P} / \mathbf{R}$ & 65 & 60 & Yes & No \\
\hline 24 & $\mathbf{P}$ & 90 & 45 & (Yes) & No & $\mathbf{R}$ & 20 & 48 & Yes & No \\
\hline 25 & $\mathbf{P}$ & 82 & 70 & No & No & $R / D$ & 7 & 36 & Yes & (Yes) \\
\hline 26 & $\mathbf{P}$ & 125 & 150 & No & No & R/D & 26 & 38 & Yes & No \\
\hline 27 & $\mathbf{R}$ & 4 & 23 & Yes & Yes & D & 0 & 5 & Yes & Yes \\
\hline 28 & $\mathbf{P}$ & 87 & 110 & No & No & $\mathbf{R}$ & 26 & 44 & Yes & No \\
\hline 29 & $\mathbf{P}$ & 12 & 15 & Yes & No & D & 0 & 3 & No & Yes \\
\hline 30 & $\mathbf{P} / \mathbf{R}$ & 4 & 15 & Yes & No & D & 0 & 3 & No & Yes \\
\hline 31 & $\mathbf{P}$ & 65 & 50 & (Yes) & No & $\mathbf{R}$ & 16 & 24 & Yes & No \\
\hline 32 & $\mathbf{P}$ & 90 & 55 & No & No & $\mathbf{P} / \mathbf{R}$ & 80 & 110 & (Yes) & No \\
\hline 33 & $\mathbf{R}$ & 12 & 20 & Yes & No & $R / D$ & 10 & 48 & Yes & (Yes) \\
\hline 34 & $\mathbf{P}$ & 65 & 30 & No & No & $\mathbf{P} / \mathbf{R}$ & 20 & 35 & Yes & (Yes) \\
\hline 35 & $\mathbf{R}$ & 0 & 4 & Yes & Yes & D & 0 & 0 & No & Yes \\
\hline
\end{tabular}




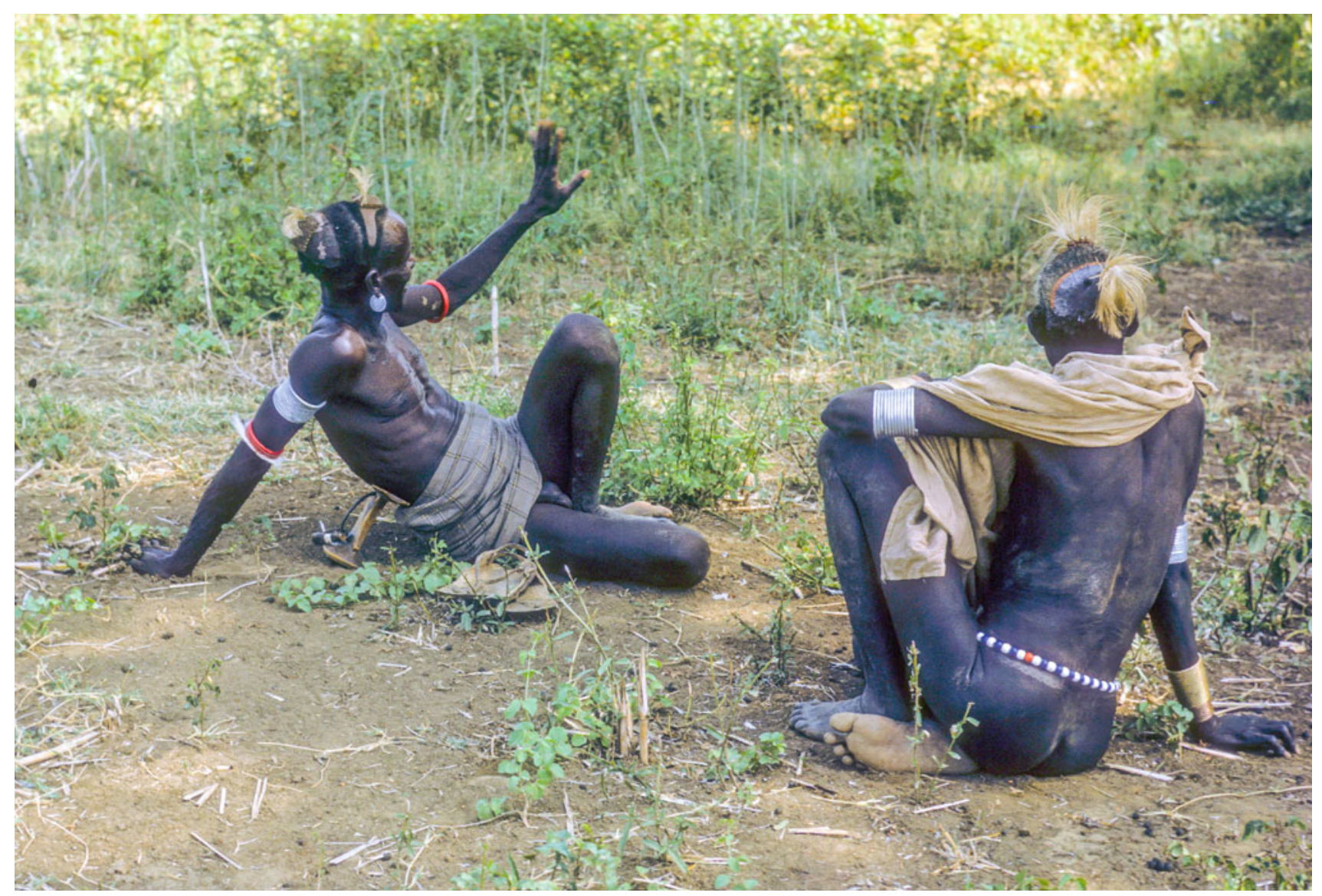

Fig. 7.10 Dasanech male elders in the Omo riverine zone

- Households with remaining livestock now depend on grazing locales within the Omo riverine and active Omo delta lands during much or all of the year. Although most Dasanech are now agropastoral, many of the households with remaining livestock depend on last resort grazing lands such as dipa-a locality of the eastern delta with relatively rich pastures. According to villagers, waters from both the Omo River and Lake Turkana sustain these grasslands.

\section{Last Resort Survival: Desperate Dependence on Omo River Annual Flood}

$>$ Most Dasanech now have major dependence on the Omo riverine zone-for flood recession agriculture, dry season and 'last resort' livestock grazing, fishing and a host of secondary production activities. All of these depend on the sustainment of the Omo River's annual flood.

Settlements and major livelihood activities in the delta vary from seasonal to semi-permanent. Most of the latter are located along the river above the maximum flood level. Including in the uppermost portion of the delta. Livestock herding in the delta fluctuates widely with seasonal changes - from short visits, especially during drought months, to year-round presence, depending on environmental and social conditions.

Dasanech households and communities practice flood recession agriculture on annually flooded waterside flats upstream from the delta, on some low riverbanks along the water's edge, and within the active delta (Fig. 7.11 ). ${ }^{6}$ Contrary to the

\footnotetext{
${ }^{6}$ Other opportunities exist for flood recession agriculture, including a few locales where backup of Omo river waters into the terminus of gathering streams (for example, Kolon - see Fig. 4.3) or incomplete channels. Some oxbow meanders well north of the Dasanech-for example, in Kara lands (Fig. 1.3) also provide conditions for flood recession agriculture when they are inundated with Omo River waters during high flow periods.
} 

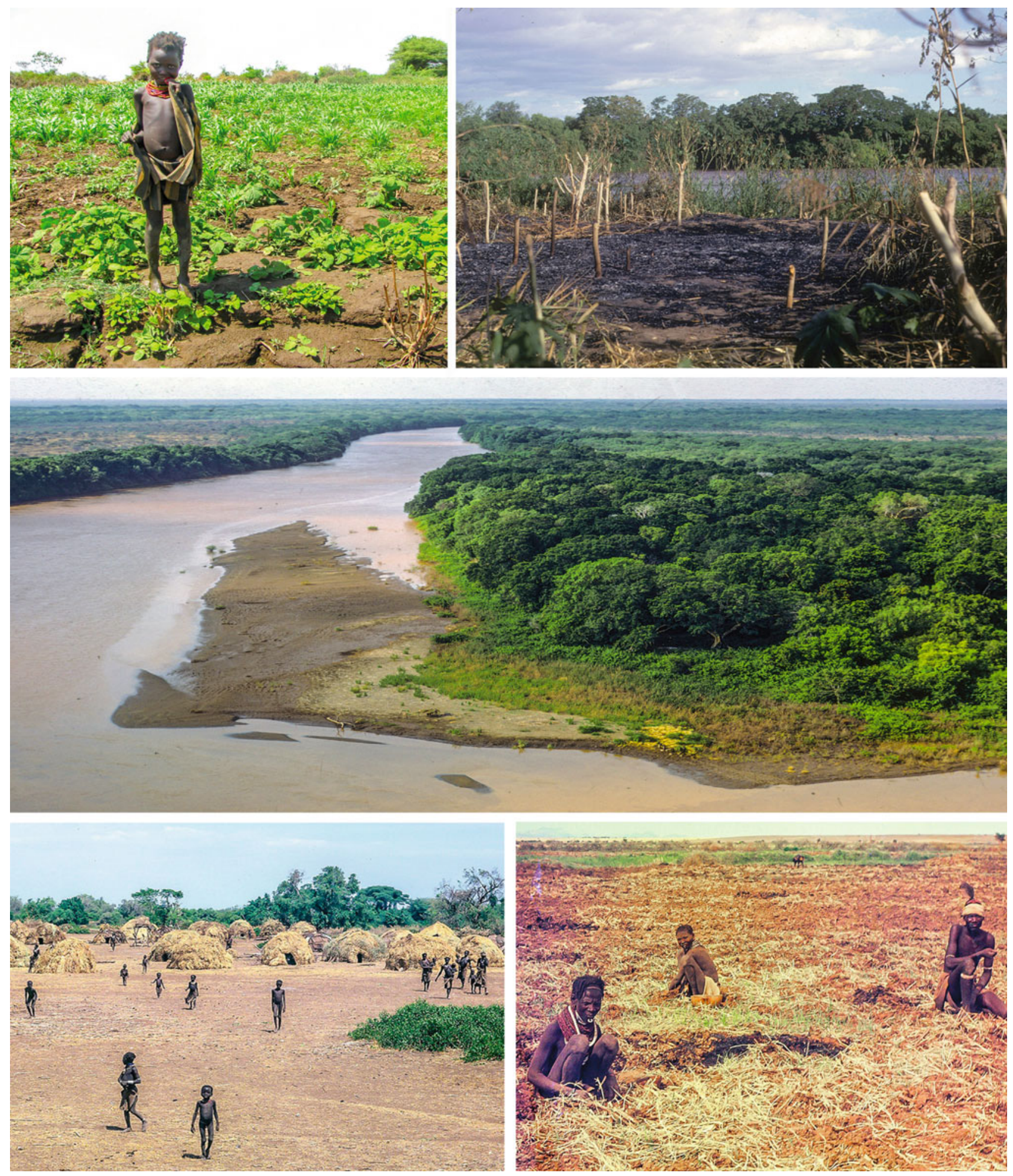

Fig. 7.11 Flood recession agriculture and Dasanech planters. Top left Dasanech girl in flood recession farm in delta. Top right agricultural plot burned prior to flood. Center Omo inside bend with sandy/silt spit—annually flooded with agricultural plot; adjacent forest does not flood. Bottom left Dasanech riverside village. Bottom right Dasanech tending farm at the river 
GOE's assertions, they do not plant in the relict floodplains because flooding does not occur in these vast flats-nor has it for thousands of years. As described in earlier chapters, overbank flooding does not occur upstream from the modern delta, except in a few small localities where there is a break in the natural levee.

Also contrary to GOE and development bank reports, rainfall in the lower Omo basin is insufficient for farming, as a brief conversation with any local resident substantiates. ${ }^{7}$

While a relatively small number of Dasanech were practicing flood recession agriculture along the Omo River well back in the twentieth century, flood dependent planting has now become the dominant means of survival for tens of thousands of villagers. In the early years, planting on seasonally flooded riverside flats was a means of minimizing risk through production diversification, rebuilding herds through bartering grain for livestock and fulfilling social obligations (see Chap. 4). Particularly after livestock losses following territorial constriction caused by government actions, extended drought, disease, and raiding by neighboring groups, Dasanech households exchanged grain from their farms along the Omo for small stock and other items. Small grain reserves were widely evident and recorded by this writer in the early 1970 s.

$\gg$ The Dasanech consistently describe their present crisis as one of too little flooding, not excessive flooding. This is true for both the active delta and the upstream waterside localities - together accounting for the majority of Dasanech settlement in recent years. Chapter 6 details the GOE's false claim of frequent major floods that are destructive of human life and property.

SONT researchers recorded these statements by Dasanech agropastoral and fishing elders.

- We have to move with our households and animals to stay close to the river channels and the delta where there is water and grass for us and our animals and where we can farm. Lands east of the river are bare and dry, except when there is good rain. We only find food and water here. [Female agropastoralist, western edge of Omo delta]

- We never had such hunger in my father's and my own time-until recently, when we became old men. Only this hunger can force us to farm and even eat fish! Herders do not eat fish-the fish eaters are the 'dies.' Our times were better. Our land was good for all Dasanech and even a man with fewer animals could eat well from his animals. The animals were healthy, and they gave much milk. We didn't have all this bush-it has come to now when we have lost our land of good grass. I used to stay with my animals in the grasslands. Now I must be at the Omo River where I have learned to farm. I must farm because my family will not eat from our few animals. Even people with many animals don't get enough milk. And when the flood doesn't come to our land, and we cannot farm, we eat fish. I don't want any more of our children to die, so we eat fish. [Riverside male elder]

$\triangleright$ Most Dasanech communities are now dependent on the Omo delta and its immediate environs for their survivalwhether for their direct use of delta resources for livestock grazing, flood recession agriculture or fishing, or their indirect but vital use of exchange relations with delta villagers.

- The southward expansion of the Omo delta to its present $500 \mathrm{~km}^{2}$ area has coincided with the Dasanech's diversification to agriculture, fishing and wild food gathering (Fig. 7.12). Large numbers of impoverished Dasanech would otherwise have faced catastrophic level conditions of hunger. As noted in previous chapters, the Omo delta was previously a limited land area with 'birdfoot' morphology (Fig. 1.2) and had few localities suitable for planting, livestock grazing and settlement.

- The total area utilized for flood recession agriculture varies widely, depending on flood conditions and multiple other factors. Based on SONT field observations and satellite photos, a medium to high range of 4000-6000 ha is a reasonable estimate for such planting - from Omorate southward to Lake Turkana, including the modern Omo delta.

\footnotetext{
${ }^{7}$ When the ephemeral Kibish River (which dissipates in the dry Sanderson's Gulf, just south of Koras Mt.) has sufficient flow, flood recession agriculture is done along the riverbanks. Presently, large numbers of Nyangatom are settled around Kibish.
} 

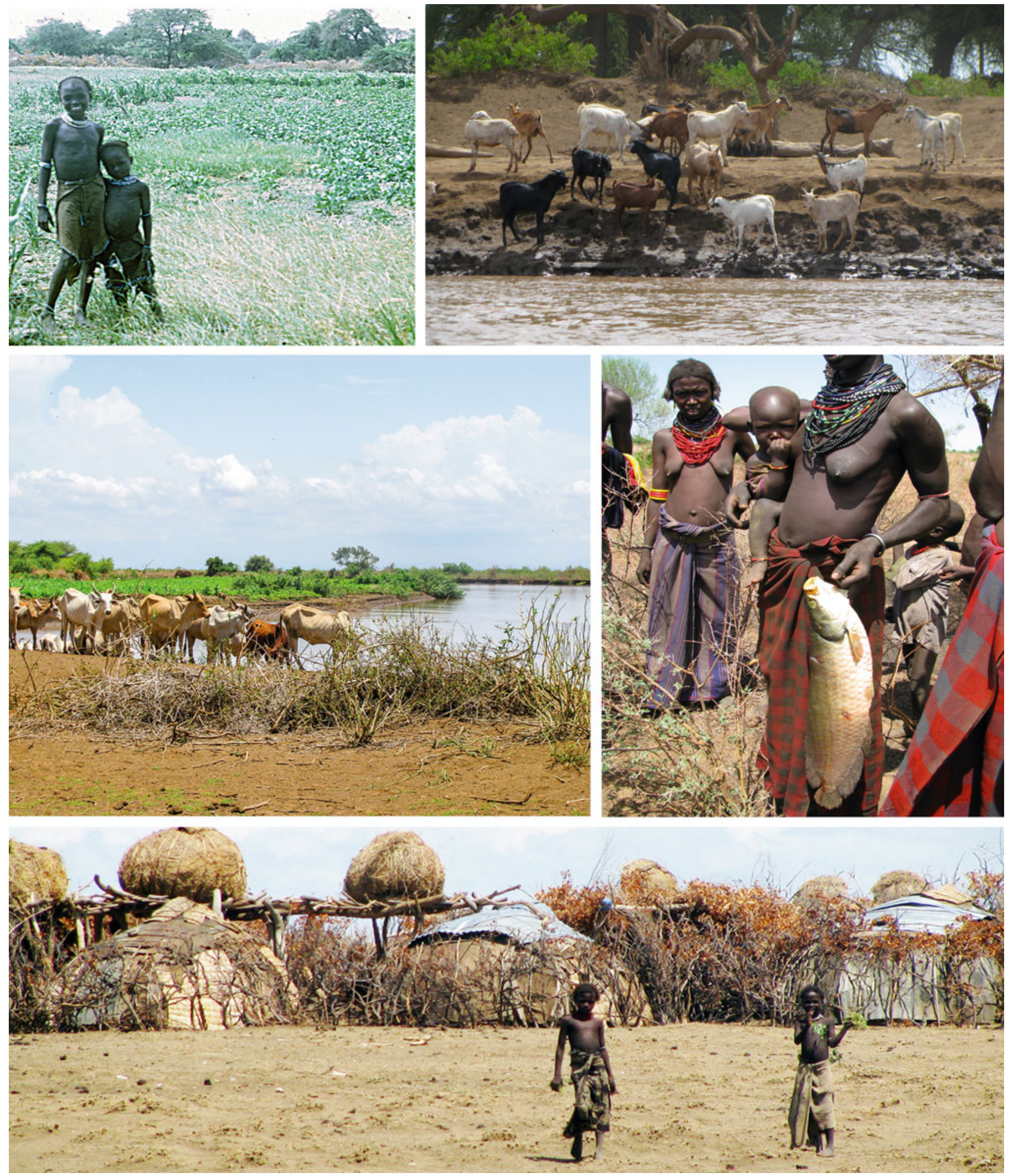

Fig. 7.12 Dasanech Life along the Lower Omo River. Top left Girls in flood recession farm near the delta; wooded natural levee in rear. Top cattle at watering. Center right East bank Dasanech fishers with catch. right Goats watering at Omo River. Center left Extremely malnourished Bottom Agropastoral village near the west bank, in the delta region 
Although no precise estimation of the number of hectares utilized for recession agriculture or the population dependent is feasible without ground-based survey and direct interviewing of local residents, an estimate of tens of thousands of Dasanech facing such destruction is entirely reasonable.

Under the present conditions of region-wide political repression and fear of Ethiopian security forces in virtually all villages, combined with the GOE's effective ban on independent research in the area, establishing reliable baseline data for the precise population under threat from loss of flood in recession agricultural lands-like the estimation of the population in general-is not possible. These data are critical for the precise assessment of the crisis unfolding,

- Environmental conditions in the delta are diverse-providing opportunities for multiple production activities that combine to provide the survival of Dasanech communities. This comment by a villager to this writer is typical in its reference to the importance of this aspect of the delta.

Many people here have some small stock, but they don't give enough milk. So a lot of people have to rely on what they can harvest from their farms. In some places, the crops do well if they get flood from the river, but in some places there is no flood and crops fail, so people have to find other ways to survive, like eating fish or buying grain from those who have it. [Dasanech female elder at village on west bank in delta area]

- Villagers throughout the delta typically are flexible in their production activities in response to their changing conditions. Both settlement locations and resource use patterns within the active delta naturally shift with changes in Omo channel morphology and the river's annual flood as well as other environmental and social factors. A majority of villages in the western portion of the delta have been relocating to its central and eastern portions due to the threat of Turkana attack, decreased annually flooded lands and reduced planting locales on the western margin, drainage conditions that favor woody vegetation (shrubs), and tsetse infestation. Villagers with calves often have no option but to have them graze crop stubble (Fig. 7.13) when floods are insufficient to replenish vegetation in their locales.

Dasanech village settlement areas and flood recession agriculture locales active at the time of SONT research are indicated in Figs. 7.9 and 7.14. Many of these locales are now expropriated (see below). The map also indicates desiccation of the region that would result from the radical reduction of the river's flow volume and inflow to Lake Turkana, brought about by the Gibe III dam and large-scale irrigation commercial agricultural along the river.

$>$ Within the modern delta, a mosaic-like pattern of different vegetation types and water conditions has developed with the recent expansion of the delta — providing habitat for livestock grazing, fishing and food gathering. The fluctuating and critically important wetland habitat and sharp transition between riverine and upland environments (on the west bank) are shown in Figs. 7.15 and 7.16. The GOE's ESIA (GOE 2009) falsely describes a far more mesic (relatively wet) environment than is in fact the case-even presenting a highly detailed vegetation map indicating an active river channel departing the river just above Omorate to Lake Turkana. This channel (locally termed Amolo, is actually a relict one. ${ }^{8}$

- Dasanech planting on low riverside flats (including point bars and low sand/silt spits) and within the modern delta plant a variety of crops, including these traditional ones:

\begin{tabular}{l|l}
\hline sorghum/millet_Dasanech name_'ruba' & Pigeon peas-gadda \\
\hline maize_nakapono & other vegetables-eri \\
\hline squash_bote; gourds_turum & tobacco-tampo \\
\hline sweet potato_lokoto & beans_am haamo
\end{tabular}

\footnotetext{
${ }^{8}$ The significance of this misrepresentation is that it suggests the existence of a relatively "favorable" environment for 'alternative' resource use by the Dasanech. In fact, this channel is an ancient one and the channel hasn't flowed for many years. Formerly an active part of the Omo River system, only pools of water form during rainy periods. The relict floodplains around the Amolo channel are generally poor soils- cracking clays and silts.
} 


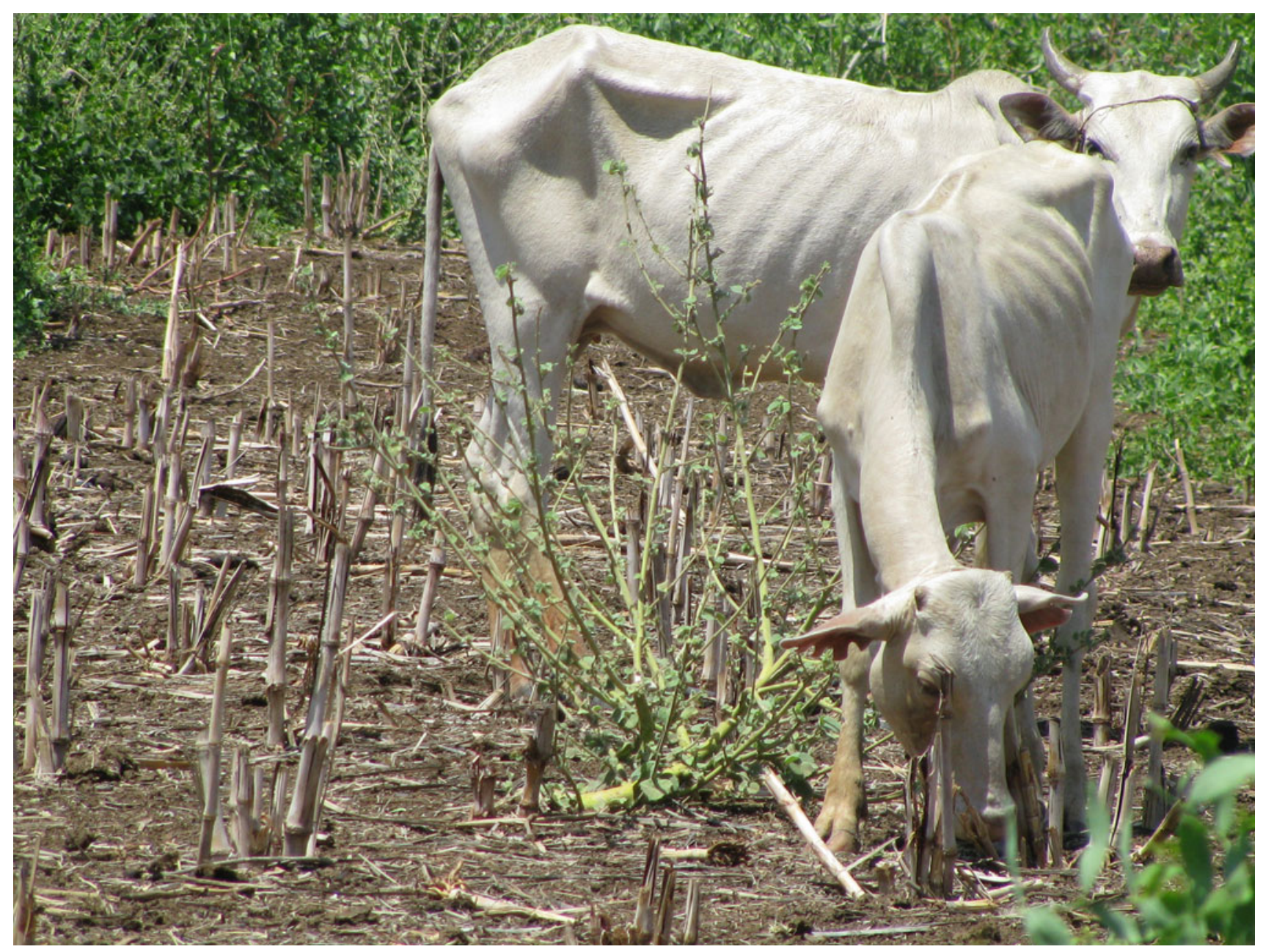

Fig. 7.13 Calves in starvation condition grazing in stubble of riverside farm plot

Except for sorghum, which is critical for meeting both subsistence and exchange needs, these crops have long been grown primarily for household consumption. Sorghum has lower water requirements than maize and it is well suited to shifting river conditions - certainly by comparison with maize. Moreover, in a good flood year, planters can produce two sorghum crops and sorghum seeds are available le from previous harvests. Beyond its importance as a household food staple, sorghum is widely traded for small stock (sheep and goats), even cattle - both within Dasanech economy and in the broad arena of interethnic exchange (Fig. 1.6). Sorghum yields are determined by multiple factors including type of sorghum planted, extent and duration of Omo River flood, soil type and land use practices. Experienced Dasanech planters up to fifteen or twenty distinct types of sorghum. "It all depends on the floodwaters," according to most respondents.

Several major soil types prevail in the delta zone where flood recession agriculture is practiced. These vary among sand, silt and clay-like textures. Although two of these (locally termed maal and digirte) are considered by most to be superior, planting is done in a wide range of soils, with different degrees of flooding. Tools are simple — primarily axes (hoolte), sticks (yugeny) and 'pangas' (nyewolo). Labor patterns are flexible, with men generally doing more of the clearing and harvesting while women perform much of the planting and weeding as well as assist in harvesting.

Labor for flood recession agriculture is highly variable among communities. Some have pervasive cooperation in most phases of farming while others have relatively sharp household delimitation of plots accompanied by limited cooperationprimarily for land preparation and harvesting. Problems of crop diseases are sometimes severe, especially from insects and rust. Dasanech villagers consistently state that the Ethiopian government has not helped them deal with these diseases; in fact, most complained of no agricultural services at all from the government. This major hardship for the river dependent Dasanech parallels that of the pastoralists. Contrary to GOE reports, village elders flatly state that they have received no 


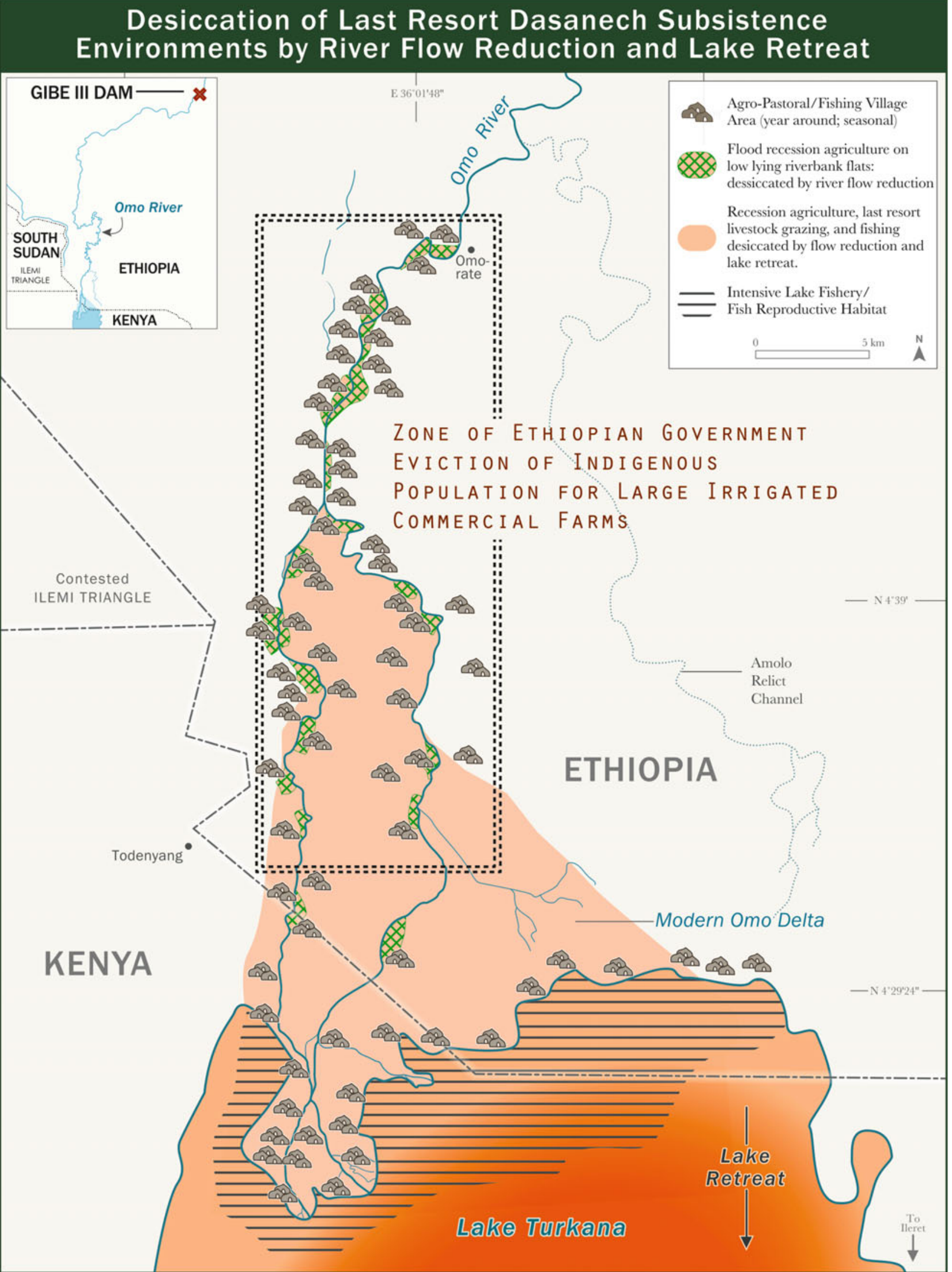

Fig. 7.14 Desiccation of modern Omo delta and northern end of Lake Turkana predictable from Gibe III dam and dam-linked irrigation systems. Destruction would include flood recession agriculture, last option grazing and fishing habitats 


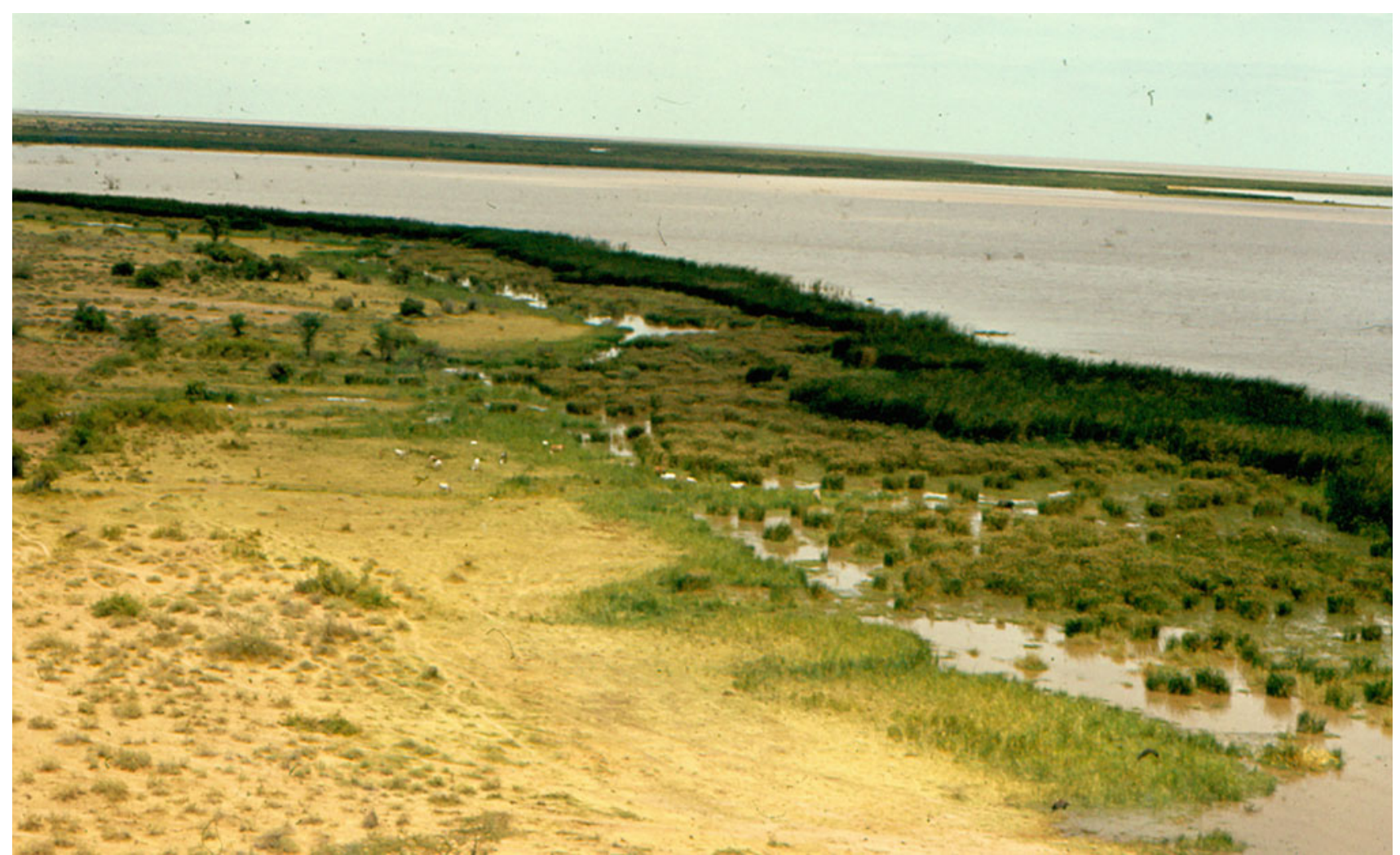

Fig. 7.15 Wetlands at the Omo delta terminus at Lake Turkana. Dasanech cattle grazing

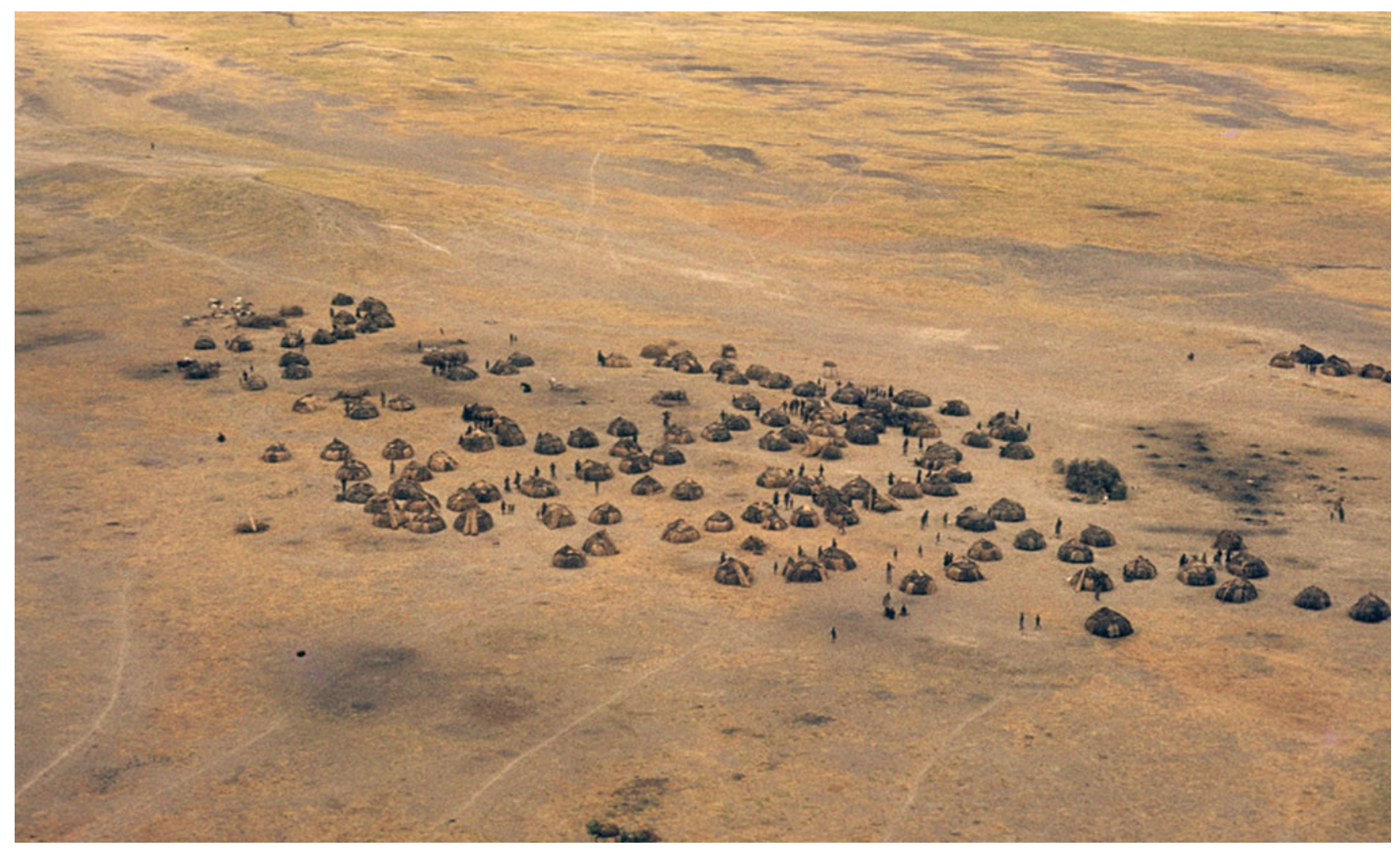

Fig. 7.16 Dasanech village complex at shoreline near northwestern extreme of Lake Turkana, close to Omo delta wetland 


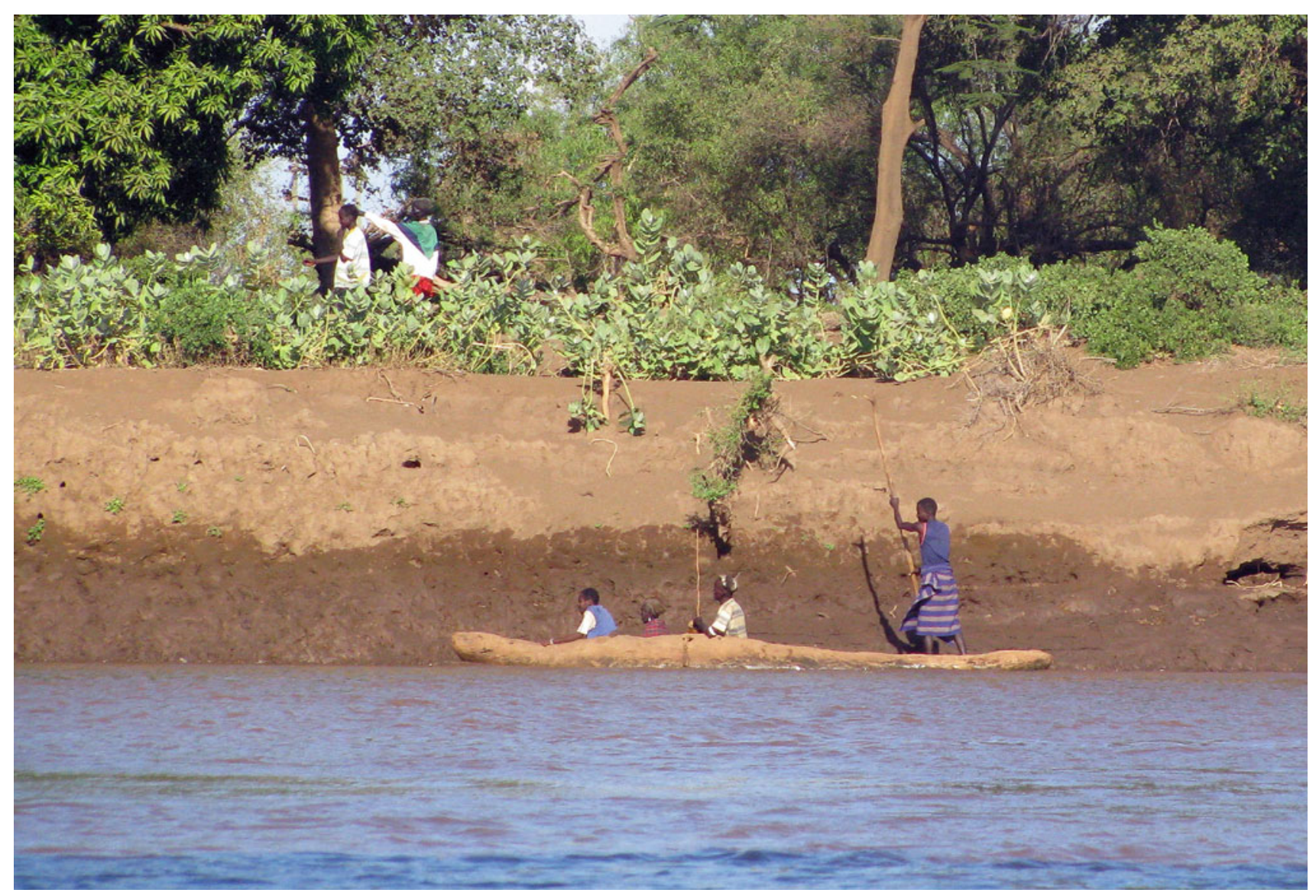

Fig. 7.17 Dasanech crossing Omo River at high flood stage for transactions between west bank residents and Omorate traders. Natural levee supports closed woodland—without overbank flooding

government assistance for the rampant and often devastating livestock diseases affecting their herds. Moreover, very few of them have access to the extremely limited NGO assistance in the area.

Dasanech knowledge and management of these conditions has been key to the sustainability of these systems - as distinct from unsustainable ones introduced and commercial style developments brought to the region by the government and private interests. When crops fail in parts of the modern delta, for example, agropastoral villagers may sell or barter some of their remaining small stock to households with more successful harvests in order to obtain sorghum.

With the retreat of Lake Turkana (Figs. 1.2 and 7.14) and expansion of the modern delta in recent decades, tree and shrub growth has increased alongside decreased flow in the main western river channel, according to local residents. Farming has declined in these areas and villages have moved to central and eastern portions of the delta where annual floods facilitating recession agriculture are more likely to occur. Even where flooding occurs in the western delta, crop yields are diminished.

$>$ Reciprocity relations between Dasanech and pastoral and agropastoral households, as well as among the region's ethnic groups, have long been critical to the survival strategies of all. These include strong east/west bank exchange relations (Fig. 7.17). Many pastoral Dasanech settled near the river plant in the delta region by negotiating labor-sharing arrangements with households there. For example, livestock owned by the delta residents are sometimes sent to stock camps in Kenya-Ethiopia borderlands northwest of the lake with labor provided by herders from west bank villages. In return, west Dasanech of the east bank and eastern delta commonly trade with the Hamar to the east-especially exchanging their sorghum for Hamar small stock. They also acquire knives, axes, earthen pots and hides from the Hamar, who have better access to these highland products. Dasanech settled on the west bank and in the western delta, on the other hand, are more likely to trade their agricultural product (primarily sorghum) for Turkana small stock - conflict conditions permitting. When relations between the two groups are relatively peaceful, Turkana herds may even be permitted to graze in the delta region, in return for wet season grazing by Dasanech herds in Turkana controlled lands. 
Without a successful sorghum harvest, the Dasanech in the riverine and delta region are often forced to sell their remaining livestock in order to survive. This has in fact been the case for countless households in recent years. East bank Dasanech agropastoral households, for example, often have no alternative but to market their remaining cattle or small stock in Omorate or other markets frequented by Hamar, Arbore or Kenyan Somalis.

$>$ Wild food gathering is critical for Dasanech survival, especially during harsh times. These include periods of prolonged drought when livestock milk and other products are reduced or when for example, the omo annual flood is insufficient for agriculture or for successfull fishing. The poorest Dasanech — those without livestock or farm plots—rely on this food source much of the time, particularly in recent times.

Most wild food gathering is done in the riverine and delta zones-precisely the environments most in line for desiccation from the destroyed from the effects of the Gibe III dam and irrigated commercial agricultural enterprises.

$>$ Fishing is done by thousands of Dasanech households and is key to survival of most of them. It is no longer limited to the 'poorest of the poor' communities and households. The critical role that fishing, as well as recession agriculture, has Agriculture have come to play, in the face of major herd decline, is stated by this elder in the southeastern Omo delta:

We eat fish every day. If others have sorghum, they will cook it and eat it. Some of us have been fishing for a long time - more than those others. Other Dasanech came to join us after they lost their cattle and small stock from drought and disease. Thousands of us are here! Many of our people died because they had nothing to eat—and before they could get here to try to plant or fish.

- Fishing communities utilize their catch for varying combinations of domestic consumption and exchange-whether barter or cash sale in local markets. Dasanech fishers exploit whatever river and lake locales they can access, depending on Omo River flow patterns and annual flood occurrence, seasonal shifts in fish life cycles, availability of fishing gear, security conditions and other factors. Major fishing areas include the lowermost Omo and fringing Omo delta channels and the nutrient-rich waters along Lake Turkana's northern shoreline - waters nourished by the river's annual freshwater and 'pulse' that sustains fish reproductive locales there (Figs. 5.2 and 7.14).

The most common fish caught by the Dasanech at the mouth of the Omo channels and along Lake Turkana's northern shoreline are tilapia and Nile perch. The most common catch species for the Dasanech are the same as those for Turkana fishers (see Chap. 9). Dasanech male fishers also hunt crocodile and hippo at night - the populations of which have radically dwindled to the point of endangerment ${ }^{9}$.

Many fishing households still use the simplest of technologies: metal spears and harpoons with string (from barter with other ethnic groups), locally crafted dug-out canoes fashioned from riverine forest trees (Fig. 7.8) or simple rafts constructed from doum palm trunks lashed together (see photos in Chap. 9). Others have wooden boats and nets, with additional gear. Dasanech fishers originally obtained much of their knowledge of fishing, as well as fishing technology, from the Turkana. They now acquire equipment through barter, purchase and capture. During investigations in Turkana villages along the lake's northwestern shoreline, for example, this writer recorded numerous accounts of violencekillings as well as gear thefts - between Turkana and Dasanech fishers.

$>$ Dasanech fishers report rapidly declining fish catch, especially with the incursion of commercial fishing fleets based in Ethiopia-companies promoted and protected by the GOE. Commercial catch is primarily destined for urban Ethiopian and export markets. Efforts to develop facilities for fish refrigeration and processing were initiated by the GOE for years, with active solicitation of investment by the SNNPR and federal government by the early years of this writer's investigation, when three major companies were active in the lowermost river and in Kenya's Lake Turkana.

\footnotetext{
${ }^{9}$ Hippos and crocodiles, like other riverine zone wildlife (elephant, buffalo, primates including colobus monkey and baboon, a wide range of reptiles, etc.) lived in abundance along a major proportion of the lower Omo river during this writer's early field work (e.g., in the early 1970s). Hunting was nearly incidental until the $1980 \mathrm{~s}$ when the GOE began developing Omorate and enterprises along the river, and when firearms became increasingly dominant in communities throughout the region. Much of the wildlife population would require restoration if this natural heritage of Ethiopia (and basis for tourism) is to be valued differently from the wholesale destruction underway. Young males - now often with little accountability to elders - often kill for sport.
} 
Company boats easily overwhelm the poorly equipped indigenous Dasanech and Turkana fishers. Villagers in the delta describe enormous fish discard (waste) by the motorized commercial boats, including large deposits of fish bones and other waste, that create major problems for their small nets and also destroy fish reproductive and feeding habitats. One Dasanech fisher responded this way when asked for his view of the foreign fishing boats:

What is bad about them is the amount of fish they kill. Some of them [fillet] the fish right there and throw the waste in the lake, so this makes the lake water poisoned. We get small nets from some of them, but mostly we are losing our fish, so nets don't help us if the fish are gone.

The Ethiopia-based fishing corporations have steadily increased their catch range into Kenya's Lake Turkana, where they are in clear violation of that nation's sovereignty. These company boats extend their fishing ventures as far southward as North Island (Figs. 1.3 and 5.2), often display the Ethiopian flag and are often accompanied by Ethiopian guard boats. They pay no fees to Kenya, nor do they obtain fishing licenses or make catch reports to Kenya's local Beach Management Units.

Turkana representatives from villages along the northwestern shoreline have appealed to the Kenyan government numerous times to expel the foreign fleets, and Kenyan fisheries officials are fully aware of the situation. As of early 2015, the Kenyan government had taken no effective action, despite innumerable requests by Turkana fishers and their representativesincluding in the locally based Beach Management Units. Nor have the development banks, in their assessments of lake conditions, fishery status or socioeconomic conditions (AFDB 2009 and 2010) raised the issue of the incursion and impact of Ethiopian commercial fleets in these Kenyan waters on fish stocks and on the worsening interethnic conflict among fishers.

What amounts to state-sponsored piracy into Kenyan waters is a matter of international sovereignty, but also greatly worsens the crisis faced by vast numbers of Kenya's Turkana whose livelihood is dependent upon the lake's fishery.

$\triangleright$ Violent conflicts between Dasanech and Turkana fishers who are increasingly desperate to secure catch from these northern waters constitute a major problem in the region. The northernmost portion of the lake accounts for many of the 'hotspots' of conflict expansion (Fig.5.3).

The frequent violence over gear theft and sporadic killings noted above frequently spreads to pastoral and agropastoral communities in the region (and visa versa) with extensive series of reprisals between the two ethnic groups. The frequent points of conflict among fishers-indicated in the map of Fig. 5.3 - are also the likely points of major expansion of local conflicts into regional ones. This trend is already well underway and is greatly amplified by the plummeting of livelihood resources as a result of Gibe III dam and irrigated agricultural development.

Governmental, non-governmental and U.N.-based accounts of conflicts among fishers and in the border region generally exclude consideration of the actual causes of this mounting crisis. Instead, the 'solutions' prescribed are most often either interethnic 'mediation' - without account of the real dynamics at play — or additional militarization by the Ethiopian and Kenyan governments, or both.

\section{Ethiopian Expropriation and Political Repression of Riverine Communities}

The Ethiopian government is engaged in extensive and systematic human rights violations of tens of thousands of indigenous pastoralists and agropastoralists along the Omo River, downstream from the Gibe III dam site, in order to pave the way for new commercial agricultural enterprises. Evictions of villagers and expropriation of their riverine resources by GOE police and militia frequently involve beatings and arrests - and reportedly, torture. Dasanech resistance to their dispossession nevertheless occurs, when possible. 
$>$ GOE denials of its expropriation actions are contradicted by available planning documents over many years. As detailed in Chap. 6, the Ethiopian government excluded mention of its obvious plans for such large-scale commercial farms in its environmental and social impact assessments. Gibe III feasibility and planning documents over the years-including the AFDB-funded Master Plan for the Omo River basin (Woodroofe \& Associates 1996), for example-assessed hydroelectricity and irrigation potential. The EIB 2010 assessment included a map of the GOE's projected commercial agricultural development along the river (Fig. 7.18). In 2009, this writer was directly informed of the government's ambitious plan for agricultural development and major irrigation in the lowermost basin during a discussion with a senior agricultural ministry official in Addis Ababa.

In the 1980s, the Ethiopian Derg's commitment to large-scale irrigated agricultural development on indigenous lands was evident from the Ethio-Korean project at Omorate (Fig. 7.9). The GOE and major international aid organizations have prioritized hydrodam development with agribusiness and power production over indigenous land rights since the Koka dam and Awash Valley developments during the post-war Haile Selassie years, despite well-documented disastrous impacts on the Oromo and Afar peoples in the Awash Valley (Bondestam 1974; Carr 1978; Kloos 1982), and elsewhere. (Chapter 2 outlined the early decades of comprehensive planning for dam and dam-linked irrigated agriculture in Ethopia's river basins, including this prioritization.).

The specifics of Ethiopian and foreign ownership of the commercial farm development are relatively well documented along the Omo in the traditional territory of the Mursi and neighboring groups (Fig. 1.3). Hundreds of thousands of hectares are leased or planned for Ethiopian, Indian, and European and other corporate and private investors (Human Rights Watch 2012; Oakland Institute 2011). Information presented by Turton and colleagues at the University of Oxford (available at www. mursi.org) reports that 30 of the 52 Mursi and Kwegu villages (at least $58 \%$ of them) are in areas that are either already delineated for sugar plantation development or are being offered by the government of Ethiopia for private agricultural development. According to this field-based data, the expropriation process involves $73 \%$ (114 of 157) of Mursi and Kwegu agricultural sites. Even two individual sugar block plantations total more than 162,000 ha, with a planned total of 245,000 ha for sugar plantations.

Table 7.3 indicates key concessions documented by the above-mentioned NGOs and researchers during investigations between 2010 and 2013 .

The above figures exclude enterprises underway or planned further downstream, especially the transboundary section of the river. Government prohibition of visitors and investigators has been extreme in the lowermost basin where the Dasanech and Nyangatom also face eviction, particularly since 2009. 'Observations' by international aid groups allegedly investigating possible abuses in the area (including USAID and DFID), moreover, are generally 'facilitated,' or 'informed' by the GOE itself.

The major crops planned for these commercial farms are cotton, sugar and oil palm, with agricultural product directed to international export and Ethiopian urban markets. These crops are high water consumption/chemical-requiring crops. These agribusiness industrial enterprises require major water diversion through canals and irrigation channels, as well as facilitation of chemical/waste discharge into the Omo River-both having disastrous effects on both downstream Omo and Lake Turkana peoples and environments. The extensive irrigation systems are already partially constructed and undergoing expansion. These include a large number of diesel pumps for water diversion and large canals.

$>$ Like the Mursi/Bodi ethnic residing upstream, the Dasanech and Nyangatom face major evictions by the GOE for the establishment of large-scale, irrigated commercial agriculture and supporting infrastructure. While it is known that private investors along the lower Omo River are from Ethiopia, India, China, Europe and the U.S., but information regarding specific individual, corporate and government owners of these irrigated commercial farms are difficult to obtain due to the GOE's refusal of access to the area by investigators and to the government's policy of extreme surveillance. All of these effectively prohibit local residents from providing information and places them under threat of severe reprisal. 


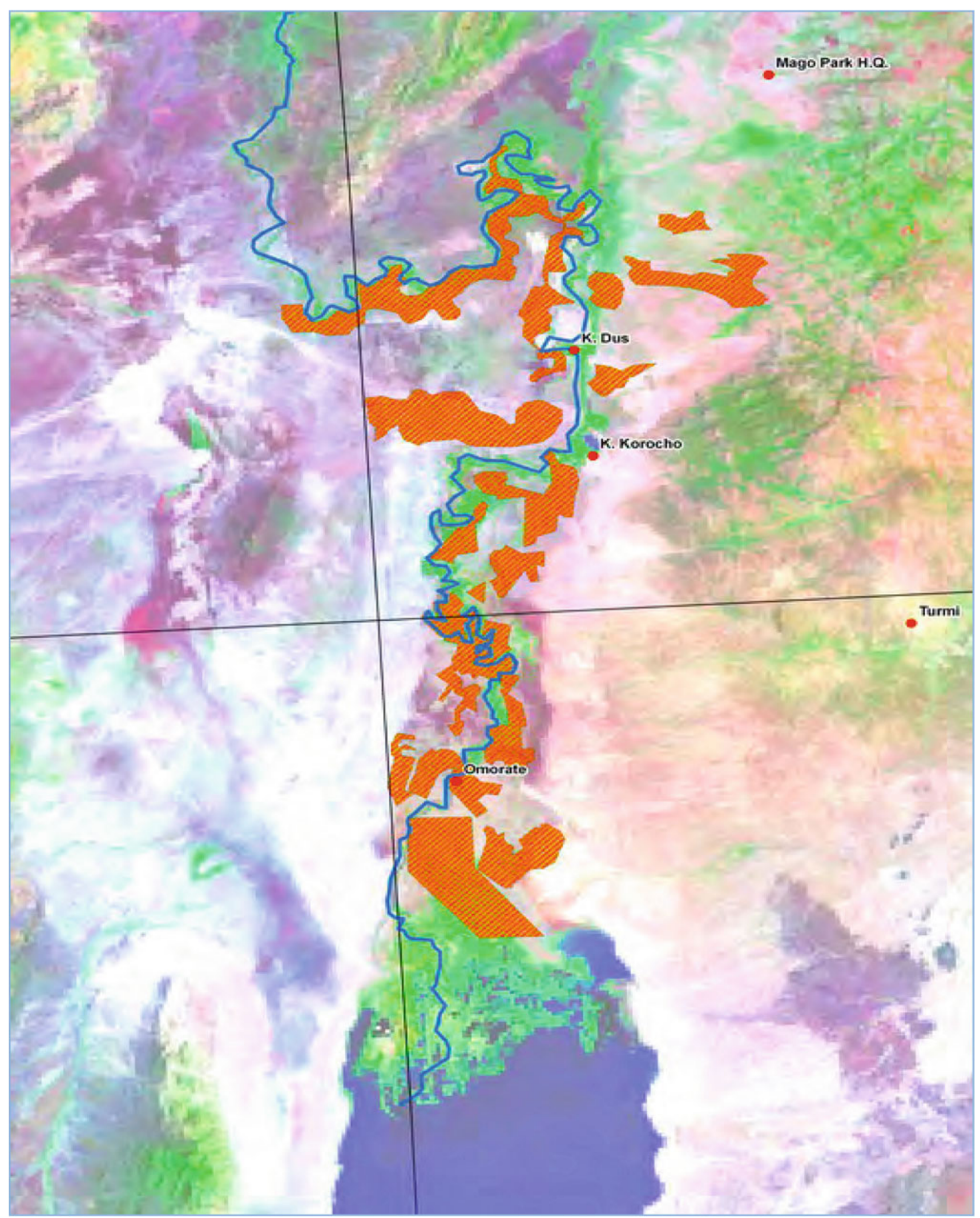

Fig. 7.18 Planned and potential irrigated agriculture in the lower Omo River basin. Some lowermost riverine zone planned farms (expropriation areas) are omitted. Source GOE map in EIB 2010 
Table 7.3 Selected irrigated agricultural enterprises in the lower Omo basin

\begin{tabular}{l|l}
\hline Plantation type and size & Owner \\
\hline $\begin{array}{l}\text { Kuraz Sugar Plantation } \\
245,000 \text { ha }\end{array}$ & $\begin{array}{l}\text { FDRE Sugar Corporation } \\
\text { (formerly Ethiopian Sugar Corporation) }\end{array}$ \\
\hline $\begin{array}{l}\text { Koka Oil Palm Plantation } \\
\text { palm oil, sesame, rubber trees }\end{array}$ & $\begin{array}{l}\text { Lim Siow Jin Estate } \\
\text { (Malaysian company) }\end{array}$ \\
\hline $\begin{array}{l}15 \text { smaller land concessions } \\
11,000 \text { ha } \\
\text { majority for cotton plantations }\end{array}$ & Various private companies \\
\hline $\begin{array}{l}\text { Oil Palm Plantation } \\
60,000 \text { ha }\end{array}$ & Fri El Green Power (Italian company) \\
\hline
\end{tabular}

Total: Minimum of 445,000 ha

Company, farm size and crop formation from Human Rights Watch (2012), Oakland Institute (2011)

Evictions of Dasanech villagers and expropriation of their recession agricultural and last resort grazing lands for these enterprises have been underway for years, along with the construction of irrigation and canal works. Political repression accompanies all of these actions since opposition is not tolerated by the GOE. The impacts are cataclysmic when they are combined with radical reduction of river and lake waters by the dam and irrigation systems.

The underreported estimate of lands seized by the GOE for commercial use along the river in Dasanech and Nyangatom traditional lands - more than 120,000 ha, according to the now outdated Human Rights Watch estimate - is vastly increased if both east and west bank commercial farms along with irrigation and canal construction are considered. ${ }^{10}$

- Evicted villagers have no realistic survival options. Nearly all households now have too few livestock to move back into a pastoral life and in any case the rangelands are severely deteriorated. Moving into the modern delta is difficult even in the 'best' of circumstances. There are already tens of thousands of Dasanech residing there or at least claiming delta lands there are suitable for flood recession agriculture. ${ }^{11}$ Residents in nearly every Dasanech village complex along the Omo River have either experienced GOE eviction or expropriation themselves or have been impacted by the influx of villagers subjected to these processes elsewhere.

- Closure of the dam would immediately initiate desiccation of the Omo delta - the very lands where the expropriated Dasanech take refuge in order to survive (Fig. 7.14). For many of them, fishing has become their last livelihood option, along with whatever success they may have in accessing flood recession planting in the already overcrowded delta.

- Last option survival by fishing along the lowermost Omo and along Lake Turkana's northern shoreline would be eliminated by the multi-kilometer retreat of that shoreline that would follow closure and early operation of the planned dam with no real reservoir water release.

Tens of thousands of Dasanech relying on annual flood in the Omo delta or who evicted from lands upstream along the river would face massive scale conditions from the impacts of the Gibe III dam and dam-linked irrigated agriculture. Figures 5.2 and 7.14 indicate the desiccation of delta and lakeshore areas caused by these developments.

The GOE's eviction of Dasanech (and Nyangatom) from their flood recession farms and settlement areas is evidence enough of the government's true development intentions in the South Omo. The government's priority of commercial development

\footnotetext{
${ }^{10}$ SONT researchers recorded specific areas of GOE eviction or expropriation of Dasanech villagers, but for political security reasons, did not attempt to quantify the size of farms being established or planned.

${ }^{11}$ Finding lands in the Omo delta for their livelihood is extremely difficult for these evicted communities, even when they have strong social ties (defined social 'segment,' or clan terms), since the Omo delta lands are already overcrowded. Some of them attempt fishing and move even closer to Lake Turkana's northern shoreline.
} 
over the survival of its indigenous population is starkly evident from its public statements and investor solicitations. The administrator of Debub Omo Zone, in an interview for Fortune magazine, stated:

We granted the land to the company along the Omo valley, which is the most suitable area for the plantation of palm oil, to encourage investors to come to the region with the prospect of exploiting this huge potential.

Dasanech village settlements and lands listed in Table 7.4 were among those expropriated by the GOE, according to local resident reporting to SONT researchers, mostly during late 2012 and early 2013.

$>$ The GOE's planning and impact assessment documents describe agricultural development plans as part of 'community development and 'social services' provision - a clear misrepresentation of the reality of the lowermost Omo region as well as GOE policies. The following false statements in the GOE's downstream impact assessment (GOE 2009) reflect this misrepresentation.

The following examples of such statements by EEPCO officials illustrates GOE fabrication of its development plans for the "benefit" of the Dasanech.

- The South Omo project area is "hardly inhabited at all except at a widely scattered pattern," and that the population density "at the South Omo project site is below five persons per square kilometer." 12

To the contrary, SONT researchers documented thousands of Dasanech living in major village complexes along the west shore of the Omo River riverine zone in proximity to one another, as indicated in Fig. 7.14. This condition is manifest, even to the casual observer visiting the riverside zone.

- The government "will not displace a single person involuntarily in Gambella, or elsewhere within the country."

Firsthand accounts by Dasanech elders, describing their evictions from settlements and lands (Table 6.4), directly contradict the government's assertions.

- An irrigated land of 0.75 ha of land each is prepared for 2050 households. There will not be any land scarcity for any family with a capacity to produce more. Training on improved agronomy practices, technology inputs and livestock management including rangeland will be provided.

This statement is also false. The communities listed in Table 7.4 are among those whose riverside farming areas or settlement areas have been expropriated. While thousands of villagers are expropriated with nowhere to go, the GOE frequently speaks of 'providing employment' for the local population. A very few Dasanech are incorporated into selected commercial farms, they are in essence wage labor, not 'participants' in local cooperative or community based development. SONT investigation of two major expropriation/farm establishments on the west bank, for example, revealed that only 20 to 30 young men were hired while hundreds of villagers were sent away.

$>$ The Ethiopian government consistently describes its 'consultation' with local communities participatory. Dasanech elders, however, consistently report that, the Ethiopian government has forcefully ordered them to vacate many of their different their village locales, as well as major grazing and recession agriculture lands.

- Development bank documents refer to the consultations carried out by the GOE, but these rely entirely on the GOE's description of its actions, not that of local residents.

- A culture of fear prevails among Dasanech villages. Omorate based GOE militia and security personnel take repressive, even violent measures against individuals and groups protesting their eviction and expropriation.

- Villagers' acts of resistance - even questioning, have been met with swift and sometimes violent action by police or militia.

\footnotetext{
${ }^{12}$ These (italicized) statements were made in a letter from the Minister of Federal Affairs in the GOE, in response to a letter from Human Rights Watch in November of 2011. They are representative of numerous statements issued by the GOE's EEPCO and other key government officials.
} 
Table 7.4 Partial list of Ethiopian government evictions and expropriations of Dasanech villagers

\section{EVICTION OF VILLAGERS AND FLOOD RECESSION CULTIVATORS: WEST BANK OF THE OMO RIVER (2009 - 2012)}

Goto: Eviction from extensive flood recession agricultural lands.

Thousands forced to evacuate to find new areas for planting and livestock grazing.

Large commercial farm established.

Damish: Eviction from extensive flood recession agricultural lands.

Most households forced to find new resource areas for planting, livestock grazing.

Large-scale irrigated commercial farm established.

Nyemomeri: Eviction from extensive flood recession agricultural lands.

Eviction of village complex (evangelical missionary operations remain).

Major canal construction westward, creating barrier to livestock movement.

Large commercial farm established; water works. (A few Dasanech - as wage labor).

Population forced to find new areas for subsistence

Villagers remaining in the region highly subject to Turkana attack.

Akudingole: Eviction from extensive flood recession agricultural lands.

Villagers forced to find new areas for livestock, flood recession agriculture,fishing

Salany (Salin/Selegn): Eviction from flood recession agricultural lands.

Highly vulnerable to attacks by Turkana; plains severely degraded by livestock overgrazing due to exclusion from riverside lands.

Many villagers forced to move, primarily into modern Omo Delta.

Kolon Lochuch: Most villagers evicted from flood recession plots.

Village remaining, but a substantial percentage of the population forced to leave in search of new planting locales.

\section{EVICTION OF VILLAGERS AND FLOOD RECESSION CULTIVATORS: EAST BANK OF THE OMO RIVER \& MODERN DELTA INTERIOR}

Afewerk/Afor: Government-run large farm - established early 2006.

Kapusie: Government-run large farm — established in 2006/2007.

Ediporon: In the modern Omo Delta; no agricultural land, but impacted by the influx of evicted villagers and their livestock into the delta.

Bokom (both west shore \& delta interior villages): impacted by new settlers and their livestock. Flood recession agriculture land heavily impacted by influx of evicted Dasanech from villages upstream. 
By local accounts, such government 'consultations' have consisted of meetings where a few government representatives and a number of 'trusted' local residents, with officials explaining the 'major benefits' that will come to the villagers as the result of the Gibe III dam and large-scale irrigation systems. One Omorate official stated to this writer that he had actually filled out the forms of "community approval."

The Dasanech (and Nyangatom) have had no real experience with small or medium scale dams, let alone knowledge of a megadam and how it would affect their lives. ${ }^{13}$

$\triangleright$ There is historical precedent for the expropriation of Dasanech lands and eviction of villagers along the Omo River. Following the overthrow of Haile Selassie in the mid-1970s, the new military regime greatly increased the government's presence in the lower Omo region. Until that time, direct government presence had little impact except when pastoral groups had been forced out of certain territories by Ethiopian and Kenyan government forces.

- The government's establishment of the 'frontier-style' town of Omorate along the east bank of the Omo (Fig. 1.3) furthered the displacement process of prior years and led to the rapid incursion of traders and other outsiders. This caused serious incidences of HIV infection, alcoholism, prostitution, and other social problems previously unknown to the indigenous communities. Within a short time, Omorate became the hub of large-scale agricultural development. The program used the rationale of settling the pastoralists. Highland agricultural officers in Addis Ababa viewed this development as "for their benefit"14

By the 1980s, Omorate emerged as the Ethiopian government's police and administrative center, as well as a town of trade. This has produced unprecedented mixing of Dasanech, Nyangatom, and Kara people and drawn substantial numbers of individuals from other ethnic areas of Ethiopia.

The 1980s incursion by the national government for agricultural 'development' and new police/administrative presence came on the heels of many years of Christian evangelical missionary presence along the lowermost Omo-a presence the government facilitated by alienating riverside common property of the Dasanech. Small numbers of local residents were included in the missionary program, with certain conditions (villagers report have to become Christianized.) Non-indigenous crops (bananas, tomatoes, mangos, cassava, etc.) have been grown rather than the traditional sorghum, beans, sweet potato, pumpkin, maize and other crops consumed by local villagers. During SONT's work, villagers had to pay fees for use of missionary provided windmills. ${ }^{15}$ The impact on local systems of traditional land tenure, food, and other product exchange, and social relations have been significant.

- The large Italian palm oil plantation being installed just north of Omorate, on the east bank of the river, is in the same locale as the Ethio-Korea Joint Agricultural Development Project — an irrigated commercial cotton plantation established in the 1980s under the Derg. Like its predecessor, the palm oil plantation is situated in silty clay soils of the ancient (relict) floodplain. These soils form numerous sinkholes and cracking networks, some of which extent to depths of more than four meters and from major landscape features easily visible from satellite photos and aerial views. The enormity of these cracks in the silty clay soils of the relict floodplains soils is evident in Fig. 7.19. Combined with the specific soil texture and high evaporation rates, these cracking features favor major salt accumulation.

The Derg's Korean-sponsored irrigated cotton venture was a failure - one repeated under subsequent non-governmental organization management with major salt concentration, radically decreased soil fertility and invasion by intractable non-indigenous plants unpalatable to livestock.

\footnotetext{
${ }^{13}$ Some Dasanech (and Nyangatom) herders are even misled by having seen very small dams (for example, $30-50 \mathrm{ft}$. ones) built across streams in nearby northwest Kenya (one is just outside of Lokitaung (Fig. 1.3), where many have traveled for trading), or in the Ilemi. Herders view all of these dams negatively, since they block stream flow and vegetation downstream that are vital for their livestock. These experiences obviously offer no basis for comprehending the enormity of a structure like the Gibe III dam.

${ }^{14}$ This writer personally discussed plans for such development with officials from the Ministry of Agriculture. They outlined their objectives of settling the Dasanech (they persisted referring to them with the longstanding Amhara term, 'Geleb',) teaching them to "grow tomatoes" and "drop their primitive ways".

${ }^{15}$ Personal communication by this writer with missionary representative on the east and west banks of the Omo River.
} 
The planned large-scale agriculture in this locale is likely to suffer the same fate as the previous cotton plantation. These soils are essentially the same in locales along the river where the GOE plans other irrigated commercial farmsas distinct from the annually flooded flats where the Nyangatom and Dasanech have long carried out recession agriculture.

$\triangleright$ The GOE carried out another large expropriation of Dasanech communal grazing land on the east bank-a roughly 10,000 ha unit south of Omorate appropriated by an Ethiopian highlander favored by the Derg. This enterprise was abandoned in 1991, following the overthrow of the military government.

This land was later partly utilized by the present government to settle allegedly "displaced people" by the large flood of 2006 and for commercial production. Individuals at this plantation reported to SONT researchers that they were ordered into the new settlement by the government, despite their wish to return to their traditional village areas after the 2006 flood subsided. Their village areas had remained intact and many were not even flooded, according to residents, yet they were ordered to move. By the new government plan, longstanding traditional tenural relations with common property and traditional exchange systems were ended. By early 2010, Dasanech farmers here reported that they were required to grow specified crops for the government's storage facility or for government controlled marketing in Omorate. The GOE states that its grain storage near Omorate, on the east bank, is "for Dasanech use" during times of hunger. Local elders insist that hunger already prevails and that there is little or no assistance from the government, even in the worst of hunger periods. The Dasanech in these government schemes view themselves as largely forced labor for the government. Since researchers other than those under strict control and independent observers are prohibited from working in the area, these descriptions from Dasanech villagers lack further detail.

GOE expropriation or eviction actions are absent from all GOE planning and impact assessment documents for the Gibe III project, as is information regarding the GOE's active solicitation of private investors for commercial Agriculture and other industrial development in the South Omo.

$>$ Increasing hunger and lack of recovery options for thousands of Dasanech eicted from their riverine locales have intensified hostilities between the Dasanech and their northern Turkana and Nyangatom neighbors, who face similar conditions. Livestock raising, thefts of fishing gear and boats, armed conflict and killings are widespread.

Locales in the transboundary region already with frequent conflict are shown in Fig.5.3. They include:

- Northernmost waters of Lake Turkana and the Omo delta region.

- Villages near the northwest lake edge, including Turkana settlement at Kenya's Todenyang and in adjacent Ethiopian lands.

- Ethiopia-Kenya borderland grazing (stock camp) areas northwest of the lake.

- Eastern Ilemi Triangle stock camp/herding locales.

Dasanech conflicts with the Nyangatom are most frequent in lands around:

- Koras Mt./ Kibish River grazing, watering and settlement areas.

- Eastern Ilemi Triangle herding and stock camp locales.

- Contested locales near the Omo River.

Violence among the region's ethnic groups has frequently provoked intervention by local government security forces based in the border areas of Ethiopia and Kenya. In the case of Ethiopia, these events frequently lead to increasing repression and harsh measures by the Ethiopian police or militia — actions that are viewed by the Dasanech as part of the GOE's evictions of their communities and continual expropriation of water and land resources vital to their survival.

Although government, international aid agency, United Nations and ecumenical statements concerning conflict in the Ethiopia-Kenya-Ilemi Triangle/South Sudan tri border region consistently cite or clearly imply 'indigenous' interethnic conflict 'natural' to the area. This is a major distortion of the historical reality of relations among these groups. 


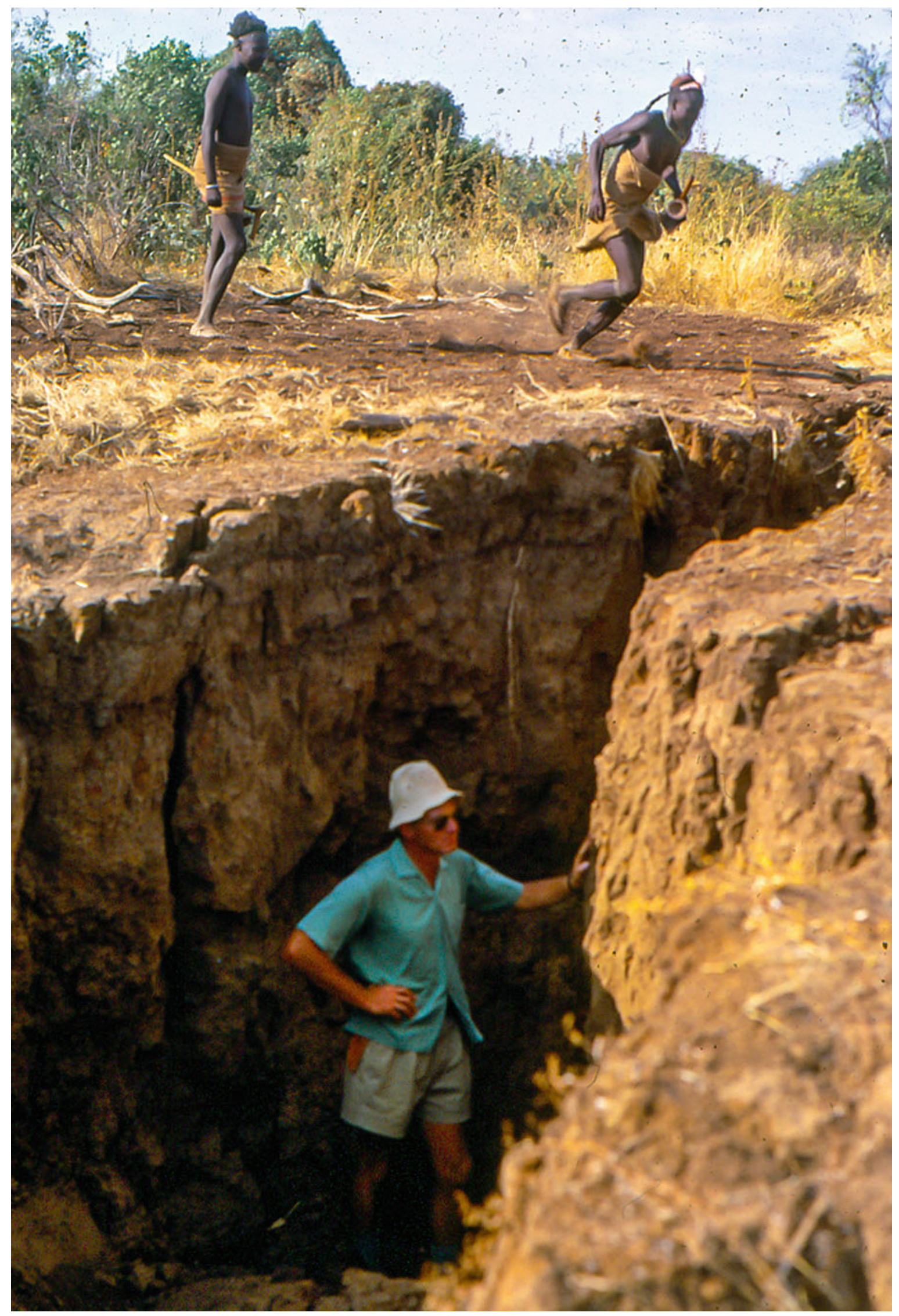

Fig. 7.19 Cracking silty clays in relict floodplains, near planned irrigated commercial farm 
While it is true that conflicts have long been common among the Nyangatom, northern Turkana, Dasanech and a number of adjacent groups, two overarching realities prevail:

- Relations among ethnic groups have long involved sporadic conflicts, but within a framework of broad, regional social and material exchange systems, as well as sharing of grazing and water resources, among others.

- Major arms trafficking in the region, especially that involving the conflict in South Sudan, has radically increased the frequency and intensity of violence.

\section{Literature Cited}

Almagor, U. 1978. Pastoral partners: Affinity and bond partnership among the Dassanetch of South West Ethiopia. Manchester: Manchester University Press, 258 pp.

Bassi, M. 2011. Primary identities in the Lower Omo Valley: Migration, cataclysm, conflict and amalgamation, 1750-1910. Journal of Eastern African Studies 5(1): 129-157.

Bondestam, L. 1974. Peoples and capitalism in the Northeast Lowlands of Ethiopia. Journal of Modern African Studies 12: 428-439.

Carr, C.J. 1977. Pastoralism in crisis: The Dassanetch of Southwest Ethiopia. Chicago: University of Chicago, Department of Geography Papers, $319 \mathrm{pp}$.

Carr, C.J. 1978. The Koka Dam, agribusiness and marginalization of the Ittu Oromo pastoralists in the Awash Valley of Ethiopia. Report to National Science Foundation, 170 pp.

Carr, C.J. 2012 Dec. Humanitarian catastrophe and regional armed conflict brewing in the border region of Ethiopia, Kenya and South Sudan: The proposed Gibe III Dam in Ethiopia. Africa Resources Working Group (ARWG), 250 pp. https://www.academia.edu/8385749/Carr_ ARWG_Gibe_III_Dam_Report.

European Investment Bank (EIB). 2010 Mar. Sogreah consultants, independent review and studies regarding the environmental \& social impact assessments for the Gibe III Hydropower Project. final Report.

Ethiopia, Government of (GOE), Ethiopian Electric Power Corporation (EEPCO). 2009. Agriconsulting S.P.A., mid-day international consulting, level 1 design, environmental and social impact assessment, additional study of downstream impacts. Report No. 300 ENV RAG 003B.

Human Rights Watch. 2012. What will happen if hunger comes? Abuses against the Indigenous Peoples of Ethiopia's Lower Omo Valley. http:// www.hrw.org/sites/default/files/reports/ethiopia0612webwcover.pdf.

Kloos, H. 1982. Development, drought, and famine in the Awash Valley of Ethiopia. African Studies Review 25(4): 21-48.

Oakland Institute. 2011. Understanding land investment deals in Africa. Country Report: Ethiopia.

Open Access This chapter is distributed under the terms of the Creative Commons Attribution-NonCommercial 2.5 International License (http:// creativecommons.org/licenses/by-nc/2.5/), which permits any noncommercial use, duplication, adaptation, distribution and reproduction in any medium or format, as long as you give appropriate credit to the original author(s) and the source, provide a link to the Creative Commons license and indicate if changes were made.

The images or other third party material in this chapter are included in the work's Creative Commons license, unless indicated otherwise in the credit line; if such material is not included in the work's Creative Commons license and the respective action is not permitted by statutory regulation, users will need to obtain permission from the license holder to duplicate, adapt or reproduce the material. 